\title{
Anti-cancer effect of Annona Muricata Linn Leaves Crude Extract (AMCE) on breast cancer cell line
}

Syed Umar Faruq Syed Najmuddin, Muhammad Firdaus Romli, Muhajir Hamid, Noorjahan Banu Alitheen and Nik Mohd Afizan Nik Abd Rahman*

\begin{abstract}
Background: Annona muricata Linn which comes from Annonaceae family possesses many therapeutic benefits as reported in previous studies and to no surprise, it has been used in many cultures to treat various ailments including headaches, insomnia, and rheumatism to even treating cancer. However, Annona muricata Linn obtained from different cultivation area does not necessarily offer the same therapeutic effects towards breast cancer (in regards to its bioactive compound production). In this study, anti-proliferative and anti-cancer effects of Annona muricata crude extract (AMCE) on breast cancer cell lines were evaluated.
\end{abstract}

Methods: A screening of nineteen samples of Annona muricata from different location was determined by MTT assay on breast cancer cell lines (MCF-7, MDA-MB-231, and $4 \mathrm{~T} 1$ ) which revealed a varied potency $\left(\mathrm{IC}_{50}\right)$ amongst them. Then, based on the $\mathrm{IC}_{50}$ profile from the anti-proliferative assay, further downward assays such as cell cycle analysis, Annexin $\mathrm{V} / \mathrm{FITC}, \mathrm{AO} / \mathrm{PI}$, migration, invasion, and wound healing assay were performed only with the most potent leaf aqueous extract (B1 AMCE) on 4 T1 breast cancer cell line to investigate its anti-cancer effect. Then, the in vivo anti-cancer study was conducted where mice were fed with extract after inducing the tumor. At the end of the experiment, histopathology of tumor section, tumor nitric oxide level, tumor malondialdehyde level, clonogenic assay, T cell immunophenotyping, and proteome profiler analysis were performed.

Results: Annona muricata crude extract samples exhibited different level of cytotoxicity toward breast cancer cell lines. The selected B1 AMCE reduced the tumor's size and weight, showed anti-metastatic features, and induced apoptosis in vitro and in vivo of the $4 \mathrm{~T} 1$ cells. Furthermore, it decreased the level of nitric oxide and malondialdehyde in tumor while also increased the level of white blood cell, T-cell, and natural killer cell population.

Conclusion: The results suggest that, B1 AMCE is a promising candidate for cancer treatment especially in breast cancer and deserves further research as an alternative to conventional drugs while also stressed out the selection of soursop sample which plays a significant role in determining its potential therapeutic effect on cancer.

Keywords: Annona muricata Linn, Breast cancer cell line, Potency, Leaf aqueous extract, Apoptosis, Anti-metastatic, Immune systems, Inflammation

Abbreviations: AMCE, Annona muricata crude extract; AO/PI, Acridine orange/propidium iodide; MDA, Malondialdehyde; MTT, 3-[4, 5-dimethylthiazol-2-yl]-2,5 diphenyltetrazolium bromide; $\mathrm{NH}_{4} \mathrm{Cl}, \mathrm{Ammonium}$ chloride; NO, Nitric oxide; PBS, Phosphate-buffered saline

\footnotetext{
* Correspondence: m.afizan@upm.edu.my

Faculty of Biotechnology and Biomolecular Sciences, Universiti Putra

Malaysia, Serdang, Selangor, Malaysia
}

(c) 2016 The Author(s). Open Access This article is distributed under the terms of the Creative Commons Attribution 4.0 International License (http://creativecommons.org/licenses/by/4.0/), which permits unrestricted use, distribution, and reproduction in any medium, provided you give appropriate credit to the original author(s) and the source, provide a link to the Creative Commons license, and indicate if changes were made. The Creative Commons Public Domain Dedication waiver (http://creativecommons.org/publicdomain/zero/1.0/) applies to the data made available in this article, unless otherwise stated. 


\section{Background}

Breast cancer is one of the leading cancer affecting women as over 1 million women worldwide are diagnosed with this disease each year [1]. Despite the current drugs present that manage to suppress the tumor growth, there is an urgent need to explore alternative strategies to overcome several limitations in treating breast cancer including the metastasis of cancerous cells which is the leading cause of mortality and morbidity, increasing the sensitivity of immune system response, and reducing the inflammation caused by cancer. With the advance of research to date, many medicinal plants have been subjected to scientific scrutiny where their secondary metabolites/bioactive compounds are discovered to have the anticancer effect potential. Annona muricata Linn which belongs to the Annonaceae family has been used in traditional medicine to treat various ailments including fever, rheumatism, cancer, and also as sedative, insecticide, and immunosuppressive activity [2]. Intensive research on the chemical composition of the leaves [3] and seeds [4] lead to the finding of acetogenin compounds which explains the therapeutic effects it possessed. Acetogenin (ACG) is characterized by its unbranched $C_{32}$ or $C_{34}$ fatty acid with a $\gamma$-lactone at the end of the cytoskeleton [5]. This molecular structure is a very potent compound against cancer as it deprives the highly energy demanding cancer cells from adenosine triphosphate (ATP) supply via the disruption of mitochondrial electron transport system, hence resulting in apoptosis [6, 7]. The production of secondary metabolites is actually a response by plants to cope with the harsh or ever changing environments. It has been reported that plant of similar species collected from different locations has a varied level of secondary metabolites among them [8] which indicates that the production of the bioactive compounds in the soursop plant could also vary thus, affecting its potency against cancer cell. As that notion has not yet been tested, therefore, the purpose of this study was to screen the cytotoxicity level of the Annona muricata crude extract (AMCE) against the breast cancer cell lines (MCF-7, MDA-MB-231, and 4 T1) as well as to further evaluate the anticancer effect possessed by the selected (most potent) AMCE on $4 \mathrm{~T} 1$ cancer in vitro and in vivo.

\section{Methods}

\section{Preparation of Annona muricata Crude Extract (AMCE)}

Samples of Annona muricata leaves were obtained from the Annona muricata cultivars in Johor, Melaka, Negeri Sembilan, Selangor, Perak, and Perlis in the months of September to November 2014. The plant was identified and deposited with a voucher number by Science Officer Lim Chung Lu from the Forestry Division, Forest Research Institute Malaysia. Details of the sampling sites and voucher number of each sample are shown in Additional file 1: Table S1. All of the 19 samples of old mature Annona muricata leaves were air-dried for a week before being ground to a powder using a grind mill. Later, about $10 \mathrm{~g}$ of each powdered samples were transferred into a Schott bottle containing $200 \mathrm{~mL}$ of cold sterile distilled water. The samples were incubated for 3 days with frequent agitation using an orbital shaker at room temperature. The mixture was then, filtered to discard any solid material/marc. Finally, the filtrate extract was dried using the freeze dryer/ lyophilizer machine to give the end product (AMCE).

\section{Cell culture}

The cell lines, MCF-7, MDA-MB-231, 4 T1 and MCF$10 \mathrm{~A}$ were obtained from the American Type Culture Collection (ATCC, Manassas, VA, USA). The MCF-7 and 4 T1 cells were maintained in RPMI 1640 medium while MDA-MB-231 cell was maintained in DMEM medium. Both media were supplemented with $10 \%$ Fetal Bovine Serum (FBS) and $1 \%$ Penicillin/Streptomycin. MCF-10A on the other hand, was maintained in DMEMF12 medium supplemented with hydrocortisone $(0.5 \mu \mathrm{g} /$ $\mathrm{mL})$, insulin $(10 \mu \mathrm{g} / \mathrm{mL})$, hEGF $(20 \mathrm{ng} / \mathrm{mL})$ and $10 \% \mathrm{FBS}$. The cells were grown in a humidified incubator at $37{ }^{\circ} \mathrm{C}$ in the presence of $5 \% \mathrm{CO}_{2}$. The cell was passaged upon reaching $70 \%$ confluency.

\section{MTT assay}

The proliferation of the cells or cell viability was assessed by the 3-[4,5-dimethylthiazol-2-yl]-2,5 diphenyltetrazolium bromide (MTT) dye reduction as described by Zhi-Dong et al [9]. The cytotoxic potential of the crude extract samples could be determined from this assay based on the $\mathrm{IC}_{50}$ generated. A hundred microliter of cells at a concentration of $0.8 \times 10^{5}$ cells/well were placed into a 96-well plate and maintained in the respective medium (RPMI/DMEM) for $24 \mathrm{~h}$. The following day, Annona muricata crude extract (AMCE) was added to the wells and then, incubated for $72 \mathrm{~h}$. MTT solutions $(5 \mathrm{mg} / \mathrm{ml})$ was added at a volume of $20 \mu \mathrm{L}$ into each wells and incubated for $3 \mathrm{~h}$. Later, the solutions were removed from wells and $100 \mu \mathrm{L}$ of DMSO were added to solubilize the formazan crystals. Finally, the plate was read using an ELISA plate reader at a wavelength of $570 \mathrm{~nm}$ (Bio-tek Instruments, USA).

\section{Annexin V/FITC assay}

The Annexin V/FITC assay was performed using Annexin V Kit (BD Pharmigen, USA) in order to analyse the potential of B1 AMCE in causing apoptosis. The cells were seeded in a 6 -well plate at a concentration of $2.4 \times 10^{5}$ cells $/ \mathrm{mL}$ and incubated overnight. On the next day, the seeded cells were treated with the $\mathrm{IC}_{50}$ value of Annona 
muricata crude extract (AMCE) and incubated for 48 and $72 \mathrm{~h}$. The cells were harvested according to the incubation time point and the resulting pellets were resuspended in the binding buffer provided. Five microliter of FITC Annexin $\mathrm{V}$ and $5 \mathrm{uL}$ of PI were added to stain the cells suspension and allowed to stand in a dark place at room temperature for $15 \mathrm{~min}$. Afterwards, the stained cells were analysed by flow cytometry machine (Becton Dickinson, USA).

\section{Acridine Orange/ Propidium lodide assay (AO/PI)}

Cell viability/apoptosis of the $4 \mathrm{~T} 1$ cells was analysed based on the AO/PI dual staining of live/dead nucleated cells. The AO/PI assay was carried out according to the protocol described by Salim et al. [10] with a slight modification. Cells were seeded in a 6 well-plate at a concentration of $2.4 \times 10^{5}$ cells $/ \mathrm{mL}$ and incubated overnight before treating with the $\mathrm{IC}_{50}$ value of Annona muricata crude extract (AMCE) the following day. The cells were incubated for another $72 \mathrm{~h}$. Afterwards, the cells were harvested and the resulted pellets were resuspended in $200 \mu \mathrm{L}$ PBS. Six microliter of the suspended cells was then stained with $4 \mu \mathrm{L} \mathrm{AO/PI}$ and the mixture were loaded onto a glass slide. The images were captured with a fluorescence microscope equipped with Nikon camera.

\section{Cell cycle assay}

To further examine the effects of B1 AMCE on the induction of apoptosis, the effects on the cell cycle was tested. The cell cycle assay was carried out using CycleTEST PLUS DNA Reagent Kit (BD Pharmigen, USA). The cells were seeded at a concentration of $2.4 \times 10^{5}$ cells $/ \mathrm{mL}$ in a 6 well-plate and incubated overnight. The next day, the seeded cells were treated with $\mathrm{IC}_{50}$ of Annona muricata crude extract (AMCE) and incubated for $72 \mathrm{~h}$. After trypsinization, cells were collected and a volume of $250 \mu \mathrm{L}$ of solution A (trypsin buffer) was added. After $10 \mathrm{~min}$ of incubation at room temperature, $200 \mu \mathrm{L}$ of solution B (trypsin inhibitor and RNase buffer) were added and the cell suspension was mixed gently. A further $10 \mathrm{~min}$ of incubation time at room temperature were required before a $200 \mu \mathrm{L}$ of cold solution C (propidium iodide stain solution) were added to stain the cells. The mixture solutions were incubated for another $10 \mathrm{~min}$ in the dark on ice before analysed by flow cytometer machine (Becton Dickinson, USA).

\section{Migration/Invasion assay}

This assay was attempted based on the predicament of the $4 \mathrm{~T} 1$ cells are able to migrate/invade with the presence of stimulants. It was conducted based on the protocol outlined by Chen [11]. Prior to the experiment, a $70 \%$ confluent $4 \mathrm{~T} 1$ cells were serum starved for $24 \mathrm{~h}$ before being seeded at a density of $2 \times 10^{5}$ cells $/ \mathrm{mL}$ in the insert chamber coated with solidified Matrigel (BD Biosciences) for the invasion assay whereas for the migration assay, the chamber was not coated by the Matrigel basement membrane. In the lower compartment of the chamber, $2 \mathrm{~mL}$ of RPMI medium supplemented with $10 \% \mathrm{FBS}$ and the desired concentration of Annona muricata crude extract was added. The inserts were incubated in a $37{ }^{\circ} \mathrm{C} \mathrm{CO}_{2}$ incubator for $24 \mathrm{~h}$. The inserts were removed afterwards and the inner side of the inserts were swabbed to remove the non-/invaded cells. The outer side of the inserts bearing the migrated/invaded cells were then fixed in methanol for $30 \mathrm{~min}$ before being stained with $0.5 \%$ of crystal violet. The images appeared on the membranes were later captured with an inverted microscope equipped with a camera (Nikon, Japan).

\section{Wound healing assay}

This assay was done using the method outlined by Liang et al. [12]. A concentration of $3.5 \times 10^{5} 4 \mathrm{~T} 1$ cells were seeded in a 6-well plate and incubated overnight. The next day, a straight wound line was drawn across the $100 \%$ confluent attached cell layer with pipette tips. The floating cells were removed with PBS and replaced with new fresh RPMI medium. Annona muricata crude extract (AMCE) was added to the wells and images of the closure of the wound were recorded at time point $0,3,6,9,12$, and $24 \mathrm{~h}$ using the inverted microscope equipped with a camera (Nikon, Japan).

\section{Animal and diet}

Six to eight-week-old female BALB/c mice were used for in vivo experiments and were obtained from UPM Animal Resource Unit. Mice were divided into groups and acclimatized for 7 days, fed with normal diet and water. All methods involving the experimental use of animals have been reviewed and approved by the Institutional Animal Care and Utilize of Committee of the Faculty Veterinary and Medicine, Universiti Putra Malaysia (Reference Number: UPM/IACUC/AUP/RO55/2015). All animals were fully conducted in humane and ethical care and under the regulation of the governing body concerning the animals.

\section{Animal treatment}

Mice were separated into 3 open-cages defining their respective groups; normal, untreated, and treated where each group bearing 7 mice per cage. Mice in the untreated and treated group were induced with $1 \times 10^{5}$ cells/mL of $4 \mathrm{~T} 1$ breast cancer cells via subcutaneous (s.c) injection using a 27 gauge needle (Teruma, USA). Mice were observed on a daily basis for about 5 days until the tumor masses develop. Treatment with Annona muricata crude extract (AMCE) of $20 \mathrm{mg} / 20 \mathrm{~g}$ mice was 
given to the treated group while the other two groups were fed with distilled water. This treatment was conducted once daily for 28 days. After 28 days of treatment, the mice were euthanized and then sacrificed by cervical dislocation. Tissue samples like tumors and vital organs which include lung and spleen were harvested and directly used in downward analysis. One-half of the tumors were placed in tubes containing $10 \%$ formalin for fixation and histological analysis while the other half were stored in tubes containing 'RNAlater' solution.

\section{Hematoxylin and eosin histology staining of the tumors}

The harvested tumors were fixed in $10 \%$ formalin and were embedded in paraffin before being sliced into thin sections. Then the paraffin sections were stained with hematoxylin and eosin $(\mathrm{H} \& \mathrm{E})$ and were viewed under a bright-field microscope (Nikon, Japan). The mitotic cells present were counted and compared between the groups.

\section{Lung clonogenic assay}

The metastasis of $4 \mathrm{~T} 1$ cells to other parts from primary tumor site was investigated by clonogenic assay. The clonogenic assay was carried out based on DuPre et al's protocol [13]. Lung organ was harvested from the untreated and treated group of mice under sterile condition and was chopped into smaller pieces as to avoid the clogging of pipette. Afterwards, it was placed in the tubes containing $5 \mathrm{~mL}$ PBS and $100 \mathrm{uL}(2 \mathrm{mg} / \mathrm{mL})$ of collagenase type IV for $30 \mathrm{~min}$ at $37{ }^{\circ} \mathrm{C}$. The solutions were passed through a $70 \mathrm{~mm}$ cell strainer and recollected in a new tube before centrifuging to obtain the pellet. The cells pellets were washed with PBS twice before being resuspended in $10 \mathrm{ml}$ RPMI medium supplemented with $10 \%$ fetal bovine serum and $60 \mu \mathrm{M}$ 6-thioguanine (Fisher, USA). The cell suspension was plated in a 6-well plate and a 1/10 serial dilution was performed to fill the other 5 wells of the same plate. The plates were incubated for 10 days in a $37 \mathrm{C}$ incubator equipped with $5 \% \mathrm{CO}_{2}$. Unattached cells were rinsed with PBS twice before the attached cells/colonies were fixed in methanol for $1 \mathrm{~h}$ and later stained with $0.5 \%$ crystal violet for another $1 \mathrm{~h}$. The wells were washed by PBS and viewed under microscope.

\section{Immunophenotyping assay}

The effect of B1 AMCE on the level of immune cells population from spleen was investigated by this assay. The spleens from the mice of all groups were harvested in a sterile condition. They were placed into a petri dish containing PBS solution and were mashed through $70 \mu \mathrm{L}$ cell strainer. The single cell suspension were washed twice with ice-cold PBS and followed by the centrifugation step. The splenocytes were resuspended in a $2 \mathrm{~mL} \mathrm{NH}_{4} \mathrm{Cl}$ lysis buffer and incubated for $10 \mathrm{~min}$ at $4{ }^{\circ} \mathrm{C}$. Later, the cells were washed with PBS and centrifuged until a clean yellow pellet obtained. The pellets were dissolved in PBS and CD3, CD4, CD8, AND NK1.1 dye (Abcam, USA) were added into tubes accordingly in dark condition and were shook at $150 \mathrm{rpm}$ for $2 \mathrm{~h}$. Afterwards, $1 \mathrm{~mL}$ of PBS was added and the tubes were centrifuged. The resulted pellets were dissolved with $600 \mathrm{uL}$ of $1 \%$ paraformaldehyde and stored in the dark place at $4{ }^{\circ} \mathrm{C}$ before being analysed by flow cytometer machine (BD, USA).

\section{MDA antioxidant assay}

The effect of B1 AMCE as antioxidant against lipid peroxidation in $4 \mathrm{~T} 1$ tumor sample was investigated on the basis of the level of malondialdehyde (MDA). Two hundred microliter of tumor sample supernatant was mixed with $800 \mu \mathrm{L}$ of PBS, $25 \mu \mathrm{L}$ of butylated hydroxytoluene $(\mathrm{BHT})$, and $500 \mu \mathrm{L}$ TCA. The mixture was vortexed and incubated on ice for $2 \mathrm{~h}$. After centrifuging at $2000 \times \mathrm{g}$ for $15 \mathrm{~min}, 1 \mathrm{~mL}$ of supernatant was taken out and transferred into tube containing $75 \mu \mathrm{L}$ of $0.1 \mathrm{M}$ EDTA and $250 \mu \mathrm{L}$ of $0.05 \mathrm{M}$ TBA. The tube was boiled in water bath for $15 \mathrm{~min}$ and then, left to cool at room temperature before read by spectrophotometer at $532 \mathrm{~nm}$ and $600 \mathrm{~nm}$ wavelengths. The result obtained was compared to MDA standard curve.

\section{Nitric oxide/Griess reagent assay}

The effect of B1 AMCE on the level of nitric oxide in 4 T1 tumor was investigated using the Griess reagent assay. It was carried out using the Griess Reagent Kit for Nitrite Determination (Life Technologies, USA). Twenty microliter of Griess reagent containing equal volume of sulfanilic acid and N-1-napthylethylenediamine dihydrochloride was mixed with $150 \mu \mathrm{L}$ of the nitritecontaining sample and $130 \mu \mathrm{L}$ of deionized water in a microplate and incubated for $30 \mathrm{~min}$ at room temperature. Standard curve was also prepared by diluting the nitrite standard solution with deionized water to give a series of concentration between 1-100 $\mu \mathrm{M}$. In place of the nitrite- containing sample, the standards were mixed with the Griess reagent and incubated in a similar manner. The absorbance of the sample and standards were read by spectrophotometer (Beckman Coultor, USA) at $548 \mathrm{~nm}$ wavelength before the nitrite concentrations corresponding to the standard plot could be evaluated.

\section{Proteomic assay}

The effect of B1 AMCE on the protein level affecting the angiogenesis process in $4 \mathrm{~T} 1$ tumor was investigated using the Raybio Mouse Angiogenesis Kit (RayBiotech, Inc.). A volume of $100 \mu \mathrm{L}$ of $1 \mathrm{x}$ Blocking Buffer is added into each well of the glass chip and incubated at room temperature for $30 \mathrm{~min}$. The Blocking Buffer were decanted and aspirated before $100 \mu \mathrm{L}$ of samples were added 
into the wells and incubated for $2 \mathrm{~h}$ at RT. Later, the samples were removed and the wells were washed with Wash Buffer I for 3 times at each 2 min interval. The glass chip assembly was submerged into a container containing Wash Buffer I and shook gently for $10 \mathrm{~min}$ and this step was repeated with the Wash Buffer II. The wash buffer was decanted before $70 \mu \mathrm{L}$ of $1 \mathrm{X}$ Biotin-conjugated Anti-cytokines were added into each wells and incubated with gentle rocking for $2 \mathrm{~h}$ at RT. After washing with Wash Buffer I and followed by Wash Buffer II, a $70 \mu \mathrm{L}$ of $1 \mathrm{X}$ Streptavidin-Fluor were added to each well and incubated in a dark room for another $2 \mathrm{~h}$ in a similar manner. The washing steps were followed after removing the streptavidin-fluor from the glass chip. Later, the glass chip was removed from its tube assembly and rinsed with deionized water. A dry glass chip was sent immediately to scanning with laser scanner (Innopsys'InnoScan) at excitation frequency of $532 \mathrm{~nm}$.

\section{Statistical analysis}

All data were expressed as the means \pm standard error of mean (S.E.M.). The analysis was performed with oneway analysis of variance (ANOVA) and the group means were compared by Duncan test. Values of $p<0.05$ were considered as statistically significant.

\section{Results}

Anti-proliferative effect of Annona muricata crude extract (AMCE) on MCF-7, MDA-MB-231, and 4 T1 cells

Cell viability was determined by comparing to the survival of cells in the untreated (negative control) cultures, which was normalised to $100 \%$. The $\mathrm{IC}_{50}$ results for the anti-proliferative effect of the 19 samples of AMCE on three different breast cancer cell lines; MCF 7, MDAMB231, and 4 T1 were shown in Table 1 . The cells were treated with 2-fold serial dilutions of AMCE for $72 \mathrm{~h}$. B1 sample was the most potent AMCE among others as it exhibited the lowest $\mathrm{IC}_{50}$ (half-maximal inhibitory concentration) for all breast cancer cell lines (MCF $7=220 \mu \mathrm{g} / \mathrm{mL}$; MDA-MB231 $=350 \mu \mathrm{g} / \mathrm{mL} ; 4 \mathrm{~T} 1=250 \mu \mathrm{g} / \mathrm{mL}$ ) as depicted in Fig. 1. Figure 1 also showed the $\mathrm{IC}_{50}$ of $\mathrm{B} 1$ AMCE on the positive control cell line, MCF-10A was considerably higher than the three cancer cell lines $(1000 \mu \mathrm{g} / \mathrm{mL})$. On the other hand, A2 and R2 samples were the least potent as both showed weak activity in inhibiting the proliferation of cancer cells as they have higher $\mathrm{IC}_{50}$ compared to the other ACME samples.

\section{B1 AMCE sample induced apoptosis in $4 \mathrm{~T} 1$ breast cancer cells}

Figures 2 and 3 showed the results of Annexin V FITC of $4 \mathrm{~T} 1$ cells after treating with the $\mathrm{IC}_{50}$ of $\mathrm{B} 1 \mathrm{AMCE}$ at two different time intervals; $48 \mathrm{~h}$ and $72 \mathrm{~h}$ respectively.
Table 1 The mean values of $\mathrm{IC}_{50}$ of all AMCE samples from MTT assay in MCF 7, MDA-MB-231, and 4 T1 cells

\begin{tabular}{|c|c|c|c|}
\hline \multirow[t]{2}{*}{ Sample } & \multicolumn{3}{|c|}{ Breast cancer cell line } \\
\hline & MCF 7 & MDA & $4 \mathrm{~T} 1$ \\
\hline J1 & $302.33 \pm 1.45^{b}$ & $347.67 \pm 1.45^{\mathrm{a}}$ & $321.67 \pm 7.27^{c}$ \\
\hline M1 & $348.33 \pm 1.67^{b}$ & $360 \pm 5.77^{\mathrm{a}}$ & $312.33 \pm 1.45^{\mathrm{e}}$ \\
\hline M2 & $547.33 \pm 3.93^{f}$ & $519.67 \pm 2.91^{f}$ & $501 \pm 3.05^{h}$ \\
\hline M3 & $349.33 \pm 2.96^{d}$ & $496.67 \pm 3.33^{\mathrm{e}}$ & $450.67 \pm 8.29^{e}$ \\
\hline M4 & $500.67 \pm 6.36^{d}$ & $600 \pm 1.16^{9}$ & $450 \pm 10.41^{9}$ \\
\hline N1 & $251.33 \pm 0.67^{d}$ & $353.67 \pm 5.93^{\mathrm{a}}$ & $449.67 \pm 1.45^{b}$ \\
\hline N2 & $648.33 \pm 4.41^{9}$ & $601.5 \pm 4.44^{9}$ & $535 \pm 7.64^{j}$ \\
\hline N3 & $550 \pm 8.66^{h}$ & $601.67 \pm 0.88^{9}$ & $599.33 \pm 7.88^{h}$ \\
\hline B1 & $221.67 \pm 1.67^{a}$ & $350 \pm 5.77^{a}$ & $251.67 \pm 6.01^{\mathrm{a}}$ \\
\hline B2 & $249.33 \pm 4.7^{d}$ & $379 \pm 3.06^{b}$ & $449.33 \pm 7.88^{b}$ \\
\hline B3 & $330 \pm 1.73^{c}$ & $348.33 \pm 4.41^{a}$ & $400 \pm 8.74^{d}$ \\
\hline A1 & $349.33 \pm 7.22^{e}$ & $461.33 \pm 9.14^{d}$ & $472.67 \pm 5.36^{\mathrm{e}}$ \\
\hline A2 & $701.67 \pm 4.41^{i}$ & $731.67 \pm 0.88^{j}$ & $646.33 \pm 1.86^{k}$ \\
\hline A3 & $453.67 \pm 1.86^{d}$ & $431.67 \pm 16.91^{c}$ & $443 \pm 3.51^{f}$ \\
\hline A4 & $302 \pm 1.53^{c}$ & $360.67 \pm 5.81^{a}$ & $400.67 \pm 2.96^{c}$ \\
\hline R1 & $702.67 \pm 1.45^{f}$ & $670.67 \pm 0.67^{i}$ & $501 \pm 6.66^{k}$ \\
\hline R2 & $799.67 \pm 0.88^{h}$ & $769.33 \pm 7.06^{k}$ & $605 \pm 5^{1}$ \\
\hline R3 & $650 \pm 5.77^{f}$ & $654.33 \pm 6.36^{\mathrm{hi}}$ & $500 \pm 7.64^{j}$ \\
\hline R4 & $620 \pm 2.89^{d}$ & $648 \pm 1.73^{h}$ & $452.67 \pm 6.23^{i}$ \\
\hline
\end{tabular}

Each data was expressed as mean \pm standard error of mean (S.E.M) of triplicate determinations. Mean values with different superscripts in the same column are significantly different $p<0.05$

The lower left quadrant of both histograms shows the population of the viable cells while the lower right quadrant represents the population of early apoptotic cells. The upper right quadrant represents the non-viable and late apoptotic/necrotic cells. There is a pattern of cell population shifting from viable cells to early apoptotic to late apoptosis/necrosis in both time-points. Based on Table 2, at the 48-hour time interval, the early apoptotic cell population increased gradually from $1.24 \% \pm 0.06 \%$ in the control group to $26.9 \% \pm 1.18 \%$ in $\mathrm{IC}_{50}$ of the treatment group whereas at 72 -hour time interval, the cells increased from $2.39 \% \pm 0.09 \%$ in the control group to $35.13 \% \pm 1.19 \%$ in the treatment group. There was also an increase in population of late apoptotic cells from $1.89 \% \pm 0.03 \%$ and $1.33 \% \pm 0.09 \%$ in the control group to $10 \% \pm 0.08 \%$ and $14.25 \% \pm 0.62 \%$ in the B1 AMCE treatment group of the 48 -h and 72-h time-point respectively. The difference of cell population percentage between 48 and 72-h time interval indicates that B1 AMCE was cytotoxic and induced apoptosis in timedependant manner. These results (48 and $72 \mathrm{~h}$ treatment) coupled with the positive results shown in the in vivo tests (later will be discussed) that involved daily 


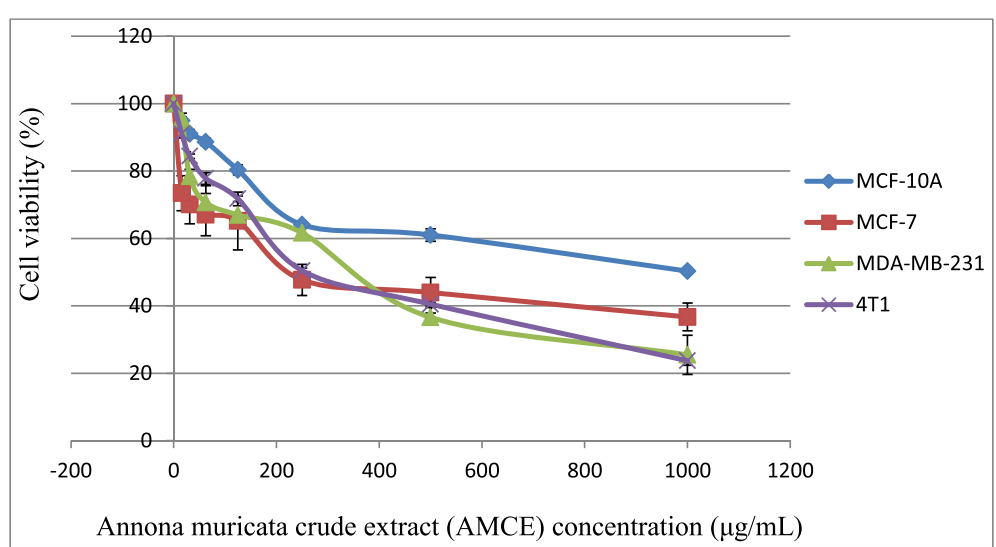

Fig. 1 Representative MTT assay showing the cytotoxicity activity of B1 AMCE in three different types of cancer cells; MCF 7, MDA-MB-231, and $4 \mathrm{~T} 1$ and normal breast cell; MCF-10A after $72 \mathrm{~h}$ of incubation in vitro

treatment for 28 days lead to the assumption that this crude extract is a potential candidate for treating breast cancer in human, as it can modulate its therapeutic effect continuously with no sign of resistance hence, effectively inhibit the growth of cancer cell in vitro and in vivo. Based on Fig. 4, the untreated 4 T1 cells were marked with distinct green intact nuclear structure colour which showed normal structure without prominent apoptosis and necrosis. On the other hand, the treated 4 T1 cells were consisted of cells population of bright green and orange-reddish colour as a result of the intercalation of $\mathrm{AO}$ and PI within the fragmented DNA, which represented the incidence of early apoptosis and late apoptosis respectively. To further study AMCE potential in inducing apoptosis, the cell cycle analysis was carried out using flow cytometric methods. Based on Fig. 5 and Table 3, after treatment with B1 AMCE
$(250 \mu \mathrm{g} / \mathrm{mL})$ for $72 \mathrm{~h}$, the percentage of cell population in the sub G0/G1 phase was significantly higher than in the control group $(4.37 \% \pm 0.20 \%$ versus $18.02 \% \pm 2.21$ in the control group). This result suggested that B1 AMCE arrested the cell cycle at the sub G0/G1 phase and induced apoptosis in vitro. On the other hand, $\mathrm{H} \& \mathrm{E}$ images of the sectioned tumors as shown in Fig. 6 indicated a decrease in the number of mitotic cells (black circles) in the B1 AMCE-treated tumor compared to the control tumor. The low mitotic number means the decline of the number of actively dividing cells, thus, inhibit the cancer cells from sustaining themselves.

Anti-metastatic potential of B1 AMCE sample on 4 T1 cells In assessing the anti-metastatic abilities of B1 AMCE, in vivo clonogenic assay and in vitro assays like wound healing analysis, migration and invasion were carried
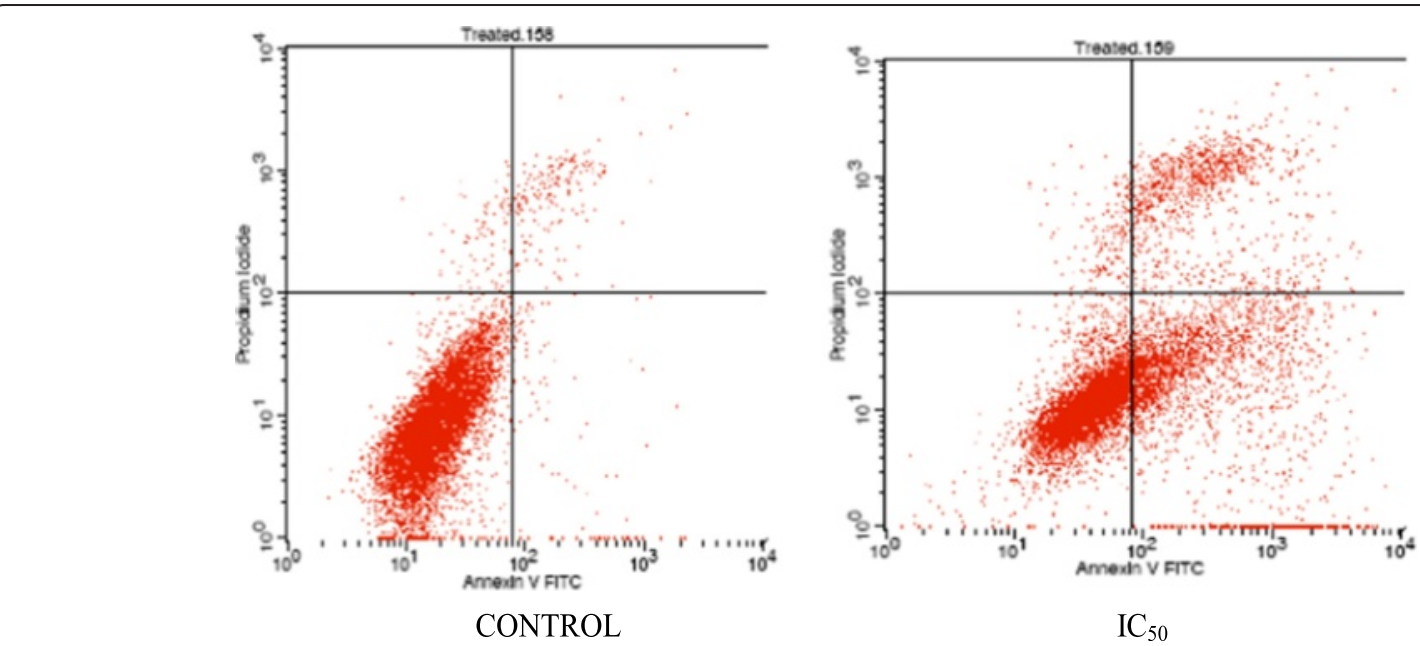

Fig. 2 Histogram analysis of Annexin V/FITC in 4 T1 cells after being treated with $\mathrm{IC}_{50}$ concentration of Annona muricata crude extract (AMCE) after $48 \mathrm{~h}$ 


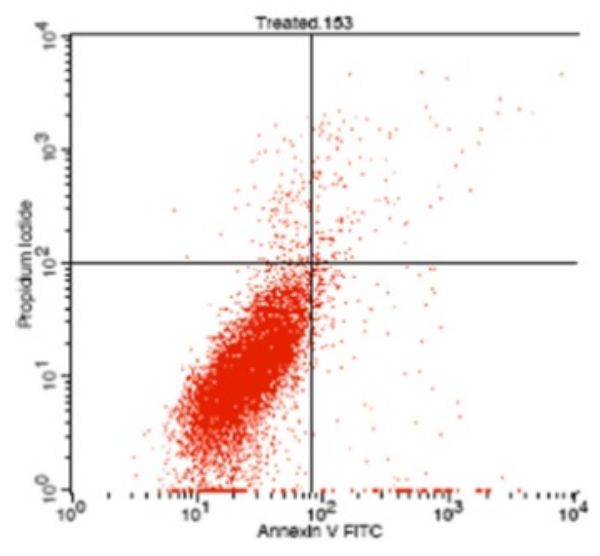

CONTROL

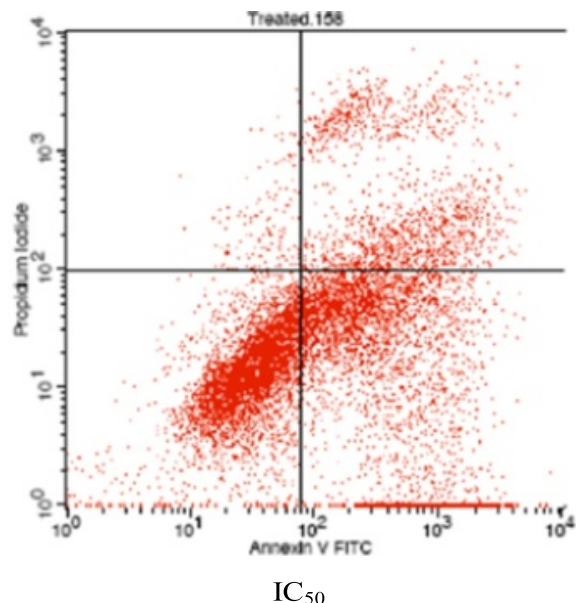

$\mathrm{IC}_{50}$

Fig. 3 Histogram analysis of Annexin V/FITC in $4 \mathrm{~T} 1$ cells after being treated with $\mathrm{IC}_{50}$ concentration of Annona muricata crude extract (AMCE) after $72 \mathrm{~h}$

out. In Fig. 7, it can be seen that there was a decrement in the percentage of wound closure in the B1 AMCEtreated 4 T1 cells, $43.9 \%$ when compared to the control group, $100 \%$. In the migration assay, only $31 \%$ of cancer cells managed to migrate through the transwell membrane when treated with B1 AMCE, as shown in Fig. 8b. This low percentage of migration rate in the treated cells compared to the control cells $(100 \%)$ indicated the potential of B1 AMCE to inhibit cancer cells migration. From the Matrigel invasion assay as shown in Fig. 9a, the ability of $4 \mathrm{~T} 1$ cells to invade a basement membrane was significantly compromised in the B1 AMCE-treated $4 \mathrm{~T} 1$ cells relative to the control cells. Quantifying this result, it was shown that treatment with B1 AMCE only allows $44 \%$ cells to invade the basement membrane relative to the control cells (Fig. 9b). These results indicated that B1 AMCE significantly inhibited the migration and invasion of $4 \mathrm{~T} 1$ breast cancer cells in vitro. The metastasis of $4 \mathrm{~T} 1$ cancer cells in mice at the distant organ such as lung was determined via clonogenic assay as depicted in Fig. 10a. In Fig. 10b, the number of colonies formed in the lung was reduced significantly in the B1 AMCE treatment group (15 \pm 0.82 ) compared to the control group $(67 \pm 2.05)$. In
Fig. 11, several angiogenesis-related proteins were tested by proteome profiler in determining the proteins level of the B1 AMCE-treated group in relative to the control/untreated group (fold change). In comparison to the control group, the level of proteins such as Eotaxin, Fas Ligand, IGF-II, IL-1 $\beta$, IL-13, Leptin, TNF- $\alpha$, and TIMP-1 were decreased in B1 AMCE-treated group $(0.83 \pm 0.01,0.68 \pm$ $0.03, \quad 0.86 \pm 0.01, \quad 0.76 \pm 0.04, \quad 0.63 \pm 0.03, \quad 0.70 \pm 0.02$, $0.83 \pm 0.01,0.990 \pm 0.04)$ respectively. However, the level of proteins likes IFN-gamma and MIG were increased $(1.32 \pm 0.39$ and $1.17 \pm 0.03)$ respectively.

\section{B1 AMCE sample impeded the growth of tumor in vivo}

The therapeutic effects of the B1 AMCE treatment in mice bearing the 4 T1-induced tumors were assessed after 28 days of treatment. Based on Fig. 12, the size of tumor in the control group are approximately similar to the B1 AMCE-treated group. However, the weight and volume of the tumor were different when compared between these two groups as shown in Figs. 13 and 14 respectively. In Fig. 13, the tumor weight decreased from $1.45 \pm 0.06 \mathrm{~g}$ in the untreated group to $1.2 \pm 0.09 \mathrm{~g}$ in the B1 AMCE-treated group. The mean tumor volume of the group treated with B1 AMCE was $271.7 \pm 14.24 \mathrm{~mm}$

Table 2 Flow cytometric analysis of phosphatidylserine externalization on 4 T1 cells after 48 and 72 h of treatment

\begin{tabular}{|c|c|c|c|c|c|}
\hline \multicolumn{2}{|c|}{ Treatment group } & \multicolumn{4}{|c|}{ Percentage of cells (\%) } \\
\hline & & \multirow{2}{*}{$\begin{array}{l}\text { Viable } \\
95.98 \pm 0.15\end{array}$} & \multirow{2}{*}{$\begin{array}{c}\text { Early apoptosis } \\
1.24 \pm 0.06\end{array}$} & \multirow{2}{*}{$\begin{array}{c}\text { Late apoptosis } \\
1.89 \pm 0.03\end{array}$} & \multirow{2}{*}{$\begin{array}{l}\text { Dead } \\
0.89 \pm 0.08\end{array}$} \\
\hline $48 \mathrm{~h}$ & Control & & & & \\
\hline & B1 AMCE & $61.48 \pm 1.13^{*}{ }_{a}$ & $26.9 \pm 1.18^{*}{ }_{a}$ & $10.01 \pm 0.08^{*}{ }_{a}$ & $1.61 \pm 0.1$ \\
\hline \multirow[t]{2}{*}{$72 \mathrm{~h}$} & Control & $95.09 \pm 0.24$ & $2.39 \pm 0.09$ & $1.33 \pm 0.09$ & $1.18 \pm 0.17$ \\
\hline & B1 AMCE & $49.39 \pm 1.74^{* *}{ }_{b}$ & $35.13 \pm 1.19^{* *}{ }_{b}$ & $14.25 \pm 0.62_{b}^{* *}$ & $1.24 \pm 0.14$ \\
\hline
\end{tabular}

Each data was expressed as mean \pm standard error of mean (S.E.M) of triplicate determinations. * Statistical significance $(p<0.05)$ between control and B1 AMCEtreated group in 48-hour time-point. ${ }^{*}$ Statistical significance $(p<0.05)$ between control and B1 AMCE-treated group in 72 -hour time-point. Mean values with different subscripts in the same column are significantly different $p<0.05$ 


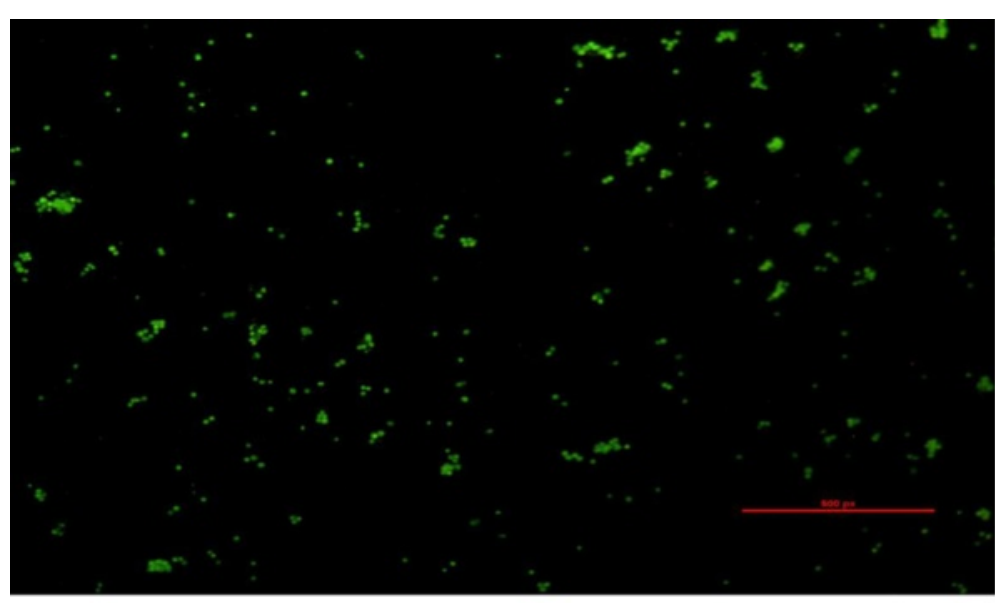

\section{Control}

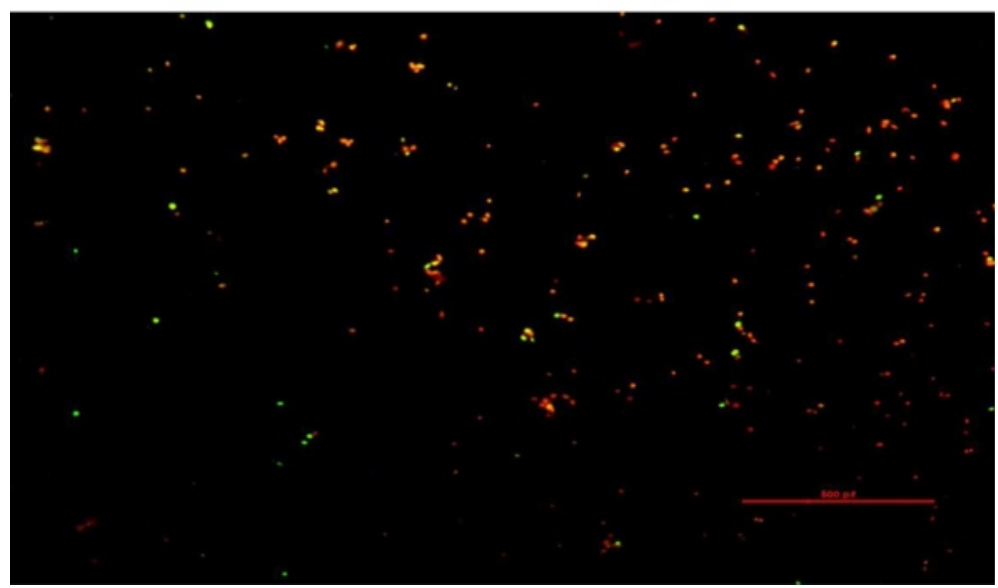

AMCE IC $_{50}$

Fig. 4 Images represent the control and treated cells which were stained with acridine orange and propidium iodide (AO/PI) after 72 h. 4 T1 cells were treated with $I_{50}$ of Annona muricata crude extract from B1 sample. Magnification: 100x

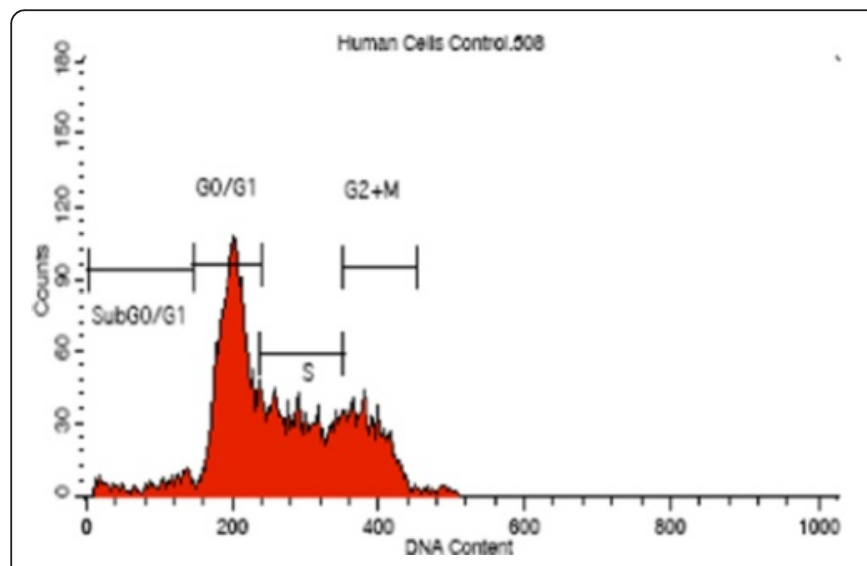

Control

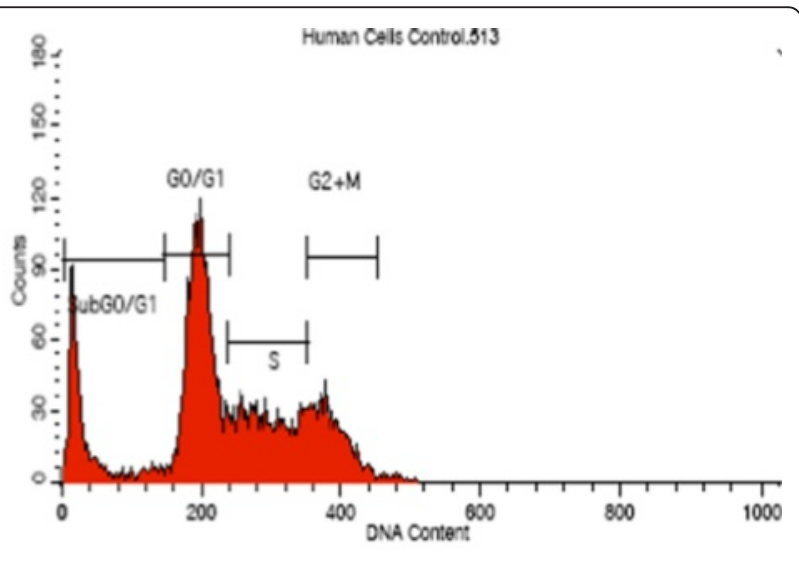

AMCE $\mathrm{IC}_{50}$

Fig. 5 Histogram analysis of the cell cycle machinery in $4 \mathrm{~T} 1$ cells after being treated with B1 Annona muricata crude extract (AMCE) after $72 \mathrm{~h}$ 
Table 3 Percentage of cells in each of the cell cycle phases after treatment with B1 AMCE for $72 \mathrm{~h}$

\begin{tabular}{lll}
\hline & Control & $I_{50}\left(250_{\mu \mathrm{g}} / \mathrm{mL}\right)$ \\
\hline Sub G0/G1 & $4.37 \pm 0.20^{\mathrm{a}}$ & $18.02 \pm 2.21^{\mathrm{b}}$ \\
G0/G1 & $45.23 \pm 0.25^{\mathrm{a}}$ & $43.12 \pm 0.75^{\mathrm{b}}$ \\
S & $29.98 \pm 0.31^{\mathrm{a}}$ & $23.48 \pm 0.93^{\mathrm{b}}$ \\
G2 + M & $20.55 \pm 0.19^{\mathrm{a}}$ & $15.39 \pm 0.70^{\mathrm{b}}$ \\
\hline
\end{tabular}

Each data was expressed as mean \pm standard error of mean (S.E.M) of triplicate determinations. Mean values with different superscripts in the same row are significantly different $p<0.05$

[3] which was smaller than the untreated group, $375 \pm$ $25.98 \mathrm{~mm}$ [3] as depicted in Fig. 14.

\section{B1 AMCE sample regulated several immune systems} markers in vivo and increase the level of white blood cell Immunophenotyping of the splenocyte cell population was carried out in order to gain the knowledge on the effect of B1 AMCE in modulating several important immune markers. In Fig. 15b, it can be seen that the splenocyte population of CD4/CD3-T cell was decreased from $25.6 \% \pm 0.11 \%$ (normal group) to $17.46 \% \pm 0.28 \%$ (control/untreated) but a significant increase was observed in the B1 AMCE-treated group (19.47 \% $\pm 0.22 \%)$. A similar trend was also observed in CD8/CD3-T cell population (Fig. 15c). A drop of CD8/CD3-T cell population percentage level was detected in the control group $(5.83 \% \pm$ $0.10 \%)$ when compared to the normal group $(12.62 \% \pm$ $0.21 \%)$ but the level of CD8/CD3- T cell population was elevated in the B1 AMCE-treated group $(6.98 \% \pm 0.23 \%)$. In addition, the population of natural killer (NK) 1.1/ $\mathrm{CD}^{+}$cell was increased in the B1 AMCE-treated group (5.73\% $\%$ 0.16\%) compared to the control/untreated group ( $4.69 \% \pm 0.13 \%$ ) as depicted in Fig. 16. Based on Table 4, the total white blood cell count observed was $4.5 \times 10^{9} / \mathrm{L}$ in the B1 AMCE-treated mice group which was higher than in the control group $\left(2.4 \times 10^{9} / \mathrm{L}\right)$.

\section{B1 AMCE regulated inflammation}

The level of nitric oxide (NO) and malondialdehyde (MDA) in the tumor were assessed in both the control group and B1 AMCE-treated group. In Fig. 17, the level of nitric oxide marked a lower level of $\mathrm{NO}$ in the treated group $(72.93 \pm 17.12 \mu \mathrm{M} / \mathrm{mg})$ compared to the control group $(123.41 \pm 20.29 \mu \mathrm{M} / \mathrm{mg})$. A similar pattern was also observed in Fig. 18 where the MDA level was decreased from $0.99 \pm 0.10 \mathrm{nM} / \mathrm{mg}$ in the control/untreated group to $0.48 \pm 0.16 \mathrm{nM} / \mathrm{mg}$ in the $\mathrm{B} 1 \mathrm{AMCE}$ treated group.

\section{Discussion}

Natural products have been the target for cancer therapy for many years due to the medicinal values contained in them. In this study, the cytotoxicity effect of the aqueous leaf extract of Annona muricata Linn samples were evaluated on three different breast cancer cell lines; MCF-7, MDA-MB-231, and 4 T1 by MTT assay. Consistent with earlier findings [14], each of the soursop crude extract exhibited the anti-cancer activity as they inhibited the proliferation of the breast cancer cell lines as depicted in Table 1 . The $\mathrm{IC}_{50}$ values are varied among the samples revealing the influence of the secondary metabolites constituents composed in them. This situation could be explained by the geographical difference of the sample cultivation area. The geographical difference of the cultivated plant means that each plant are exposed to different climate and environmental stress factors such as humidity, temperature, and soil composition [15]. The synthesis and accumulation of secondary plant products are enhanced in stress environment such as water deficit condition [16]. In harsh environment, plant adjusts their regulation of phenylpropanoid biosynthesis pathway at multiple levels in response to the exogenous factors. For example, green tea cultivated in area with high temperature, long sun exposure time, and high rainfall exhibits a higher concentration of theanine and lower concentration of leucine, isoleucine, epicatechin, and epigallocatechin compared to those cultivated in low temperature, short sun exposure time, and low rainfall [17]. Previous study had also shown that plants exposed in drought stress produce higher level of secondary metabolites indicating a crucial linkage between the environmental factor and metabolites contents [18]. In regards to those aspects, the cultivation area of B1 AMCE might be the harshest compared to the other samples hence, could be the underlying reason of its highest potency in killing cancer cells. Based on the cytotoxicity profile obtained, the aqueous leaf extract of soursop samples were more selective towards MCF-7 followed by 4 T1 and MDAMB-231 cell line. As $4 \mathrm{~T} 1$ cell line was more aggressive than the other two cell lines and also to avoid any conflict of interest, 4 T1 cell line was chosen to be used in the downward assays. B1 AMCE sample which exhibited the best $\mathrm{IC}_{50}$ profile was selected for further use to treat the 4 T1 cells. Additionally, a successful anti-cancer drug should incapacitate cancer cells without causing excessive damage to normal cells thus, indicating minimal side effects. In this study, cell viability of normal breast cells, MCF10A in the presence of B1 AMCE treatment was determined. It appeared that B1 AMCE treatment was less toxic on normal cells as it required higher dosage to kill the cells $\left(\mathrm{IC}_{50}=1000 \mu \mathrm{g} / \mathrm{mL}\right)$ which was four times higher than the $\mathrm{IC}_{50}$ of $\mathrm{B} 1 \mathrm{AMCE}$ in $4 \mathrm{~T} 1$ cells, thus, suggesting the low side effect of this plant crude extract. Flow cytometric analysis of Annexin V/ FITC at 48-h and 72-h time-point distinguished a separate population of early apoptotic, late apoptotic/necrotic cells, and living cells as a result of the employment of 


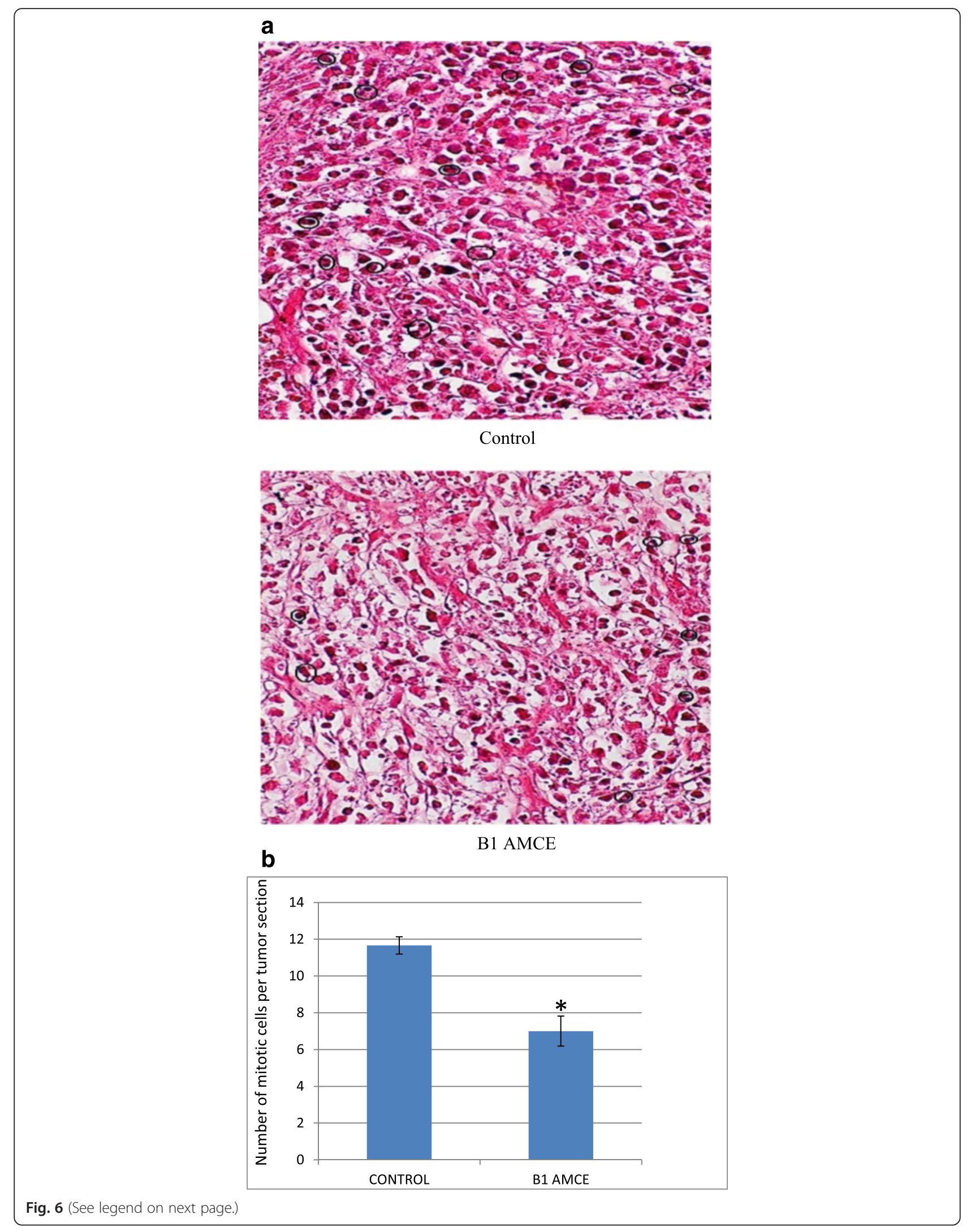


(See figure on previous page.)

Fig. 6 a Histological staining of both the tumors (control and B1 AMCE-treated) with hematoxylin and eosin (H\&E). b Quantification of histological staining of the sectioned tumors of control and B1 AMCE-treated group. The dosage used in the treated group was $20 \mathrm{mg} / 20 \mathrm{~g}$ mice B1 Annona muricata crude extract (B1 AMCE). The data are expressed as means \pm standard error of the mean for triplicates. Significance is set at ${ }^{*} p<0.05 ; n=7$ mice per group

the high affinity binding of Annexin $\mathrm{V}$ to phosphatidylserine (PS), a phospholipid component of the cell membrane. The dying cells which undergo apoptosis event experience a physiological change that causes the externalization of PS to the outer leaflet of the plasma membrane. As depicted in Table 2, the total apoptosis percentage (early apoptotic and late apoptotic/necrotic cells) in the B1 sample treatment group was higher than the untreated group. It is in accordance to the results presented in earlier report of apoptosis induction by soursop on colon cancer cells [19]. It is noteworthy that the B1 sample treatment induces the apoptosis in timedependant manner where the apoptotic cells in 72-h time-point was found higher than in the 48 -h time-point.

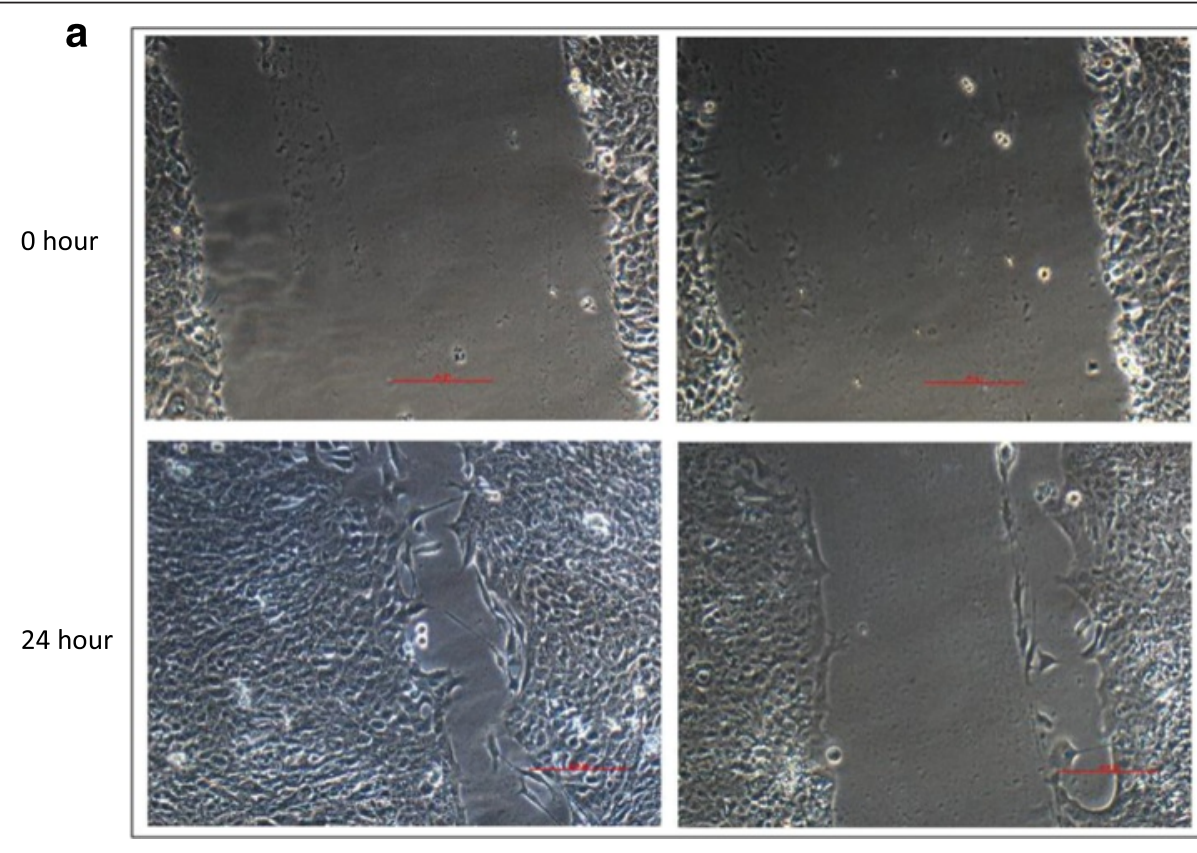

Control

Treatment

b

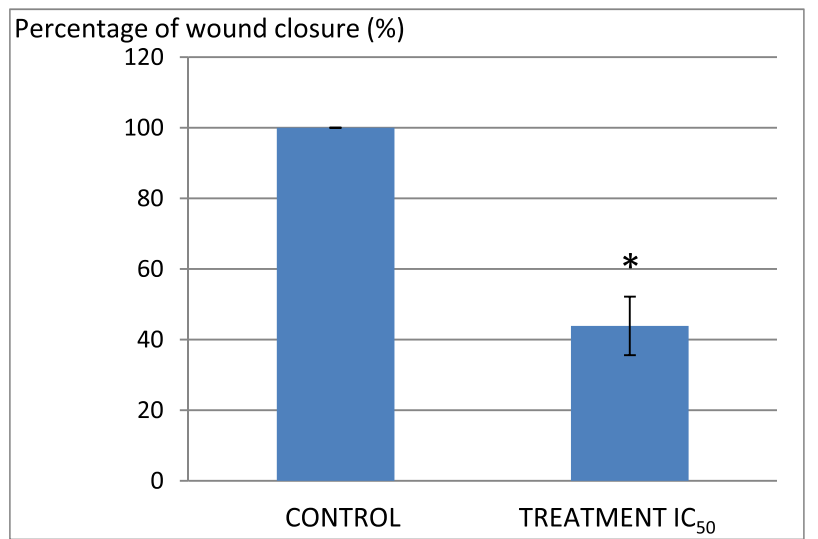

Fig. 7 a Representative images of the wound healing analysis of $4 \mathrm{T1}$ cell at $0 \mathrm{~h}$ and $24 \mathrm{~h}$ for control and cells treated with $I C_{50}$ value of B1 Annona muricata crude extract. Magnification: 100x. b Percentage of wound closure in $4 \mathrm{~T} 1$ cells when a wound is introduced. The assay was done in triplicates and the data are expressed as mean \pm standard error of mean. Significance is set at ${ }^{*} p<0.05$ 
a
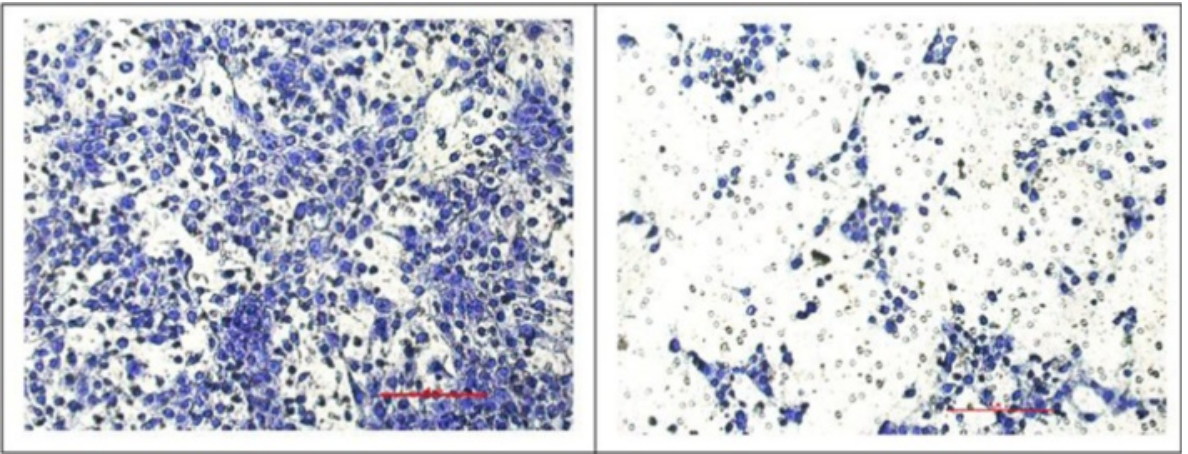

Control

$\mathrm{IC}_{50}$

b

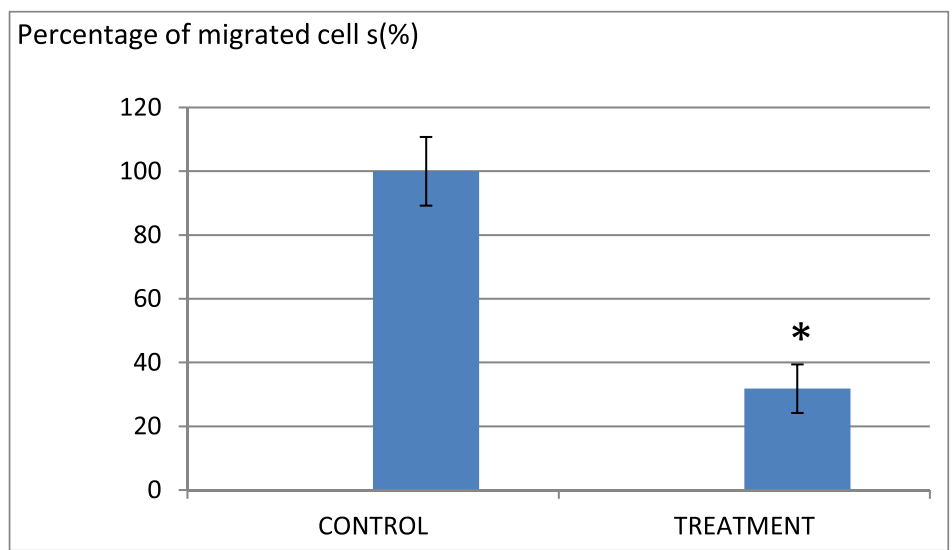

Fig. 8 a Images of the in vitro migration analysis of $4 \mathrm{~T} 1 \mathrm{cells}$; control and cells treated with $\mathrm{IC}_{50}$ value of B1 Annona muricata crude extract. The cells were allowed to migrate through an $8 \mathrm{~mm}$ pore membrane for $24 \mathrm{~h}$. $\mathbf{b}$ Quantification of migration through 8-mm pore membrane inserts (BD Biosciences) by B1 AMCE-treated $4 \mathrm{~T} 1$ cells as a percentage of that achieved by control cells. The assay was done in triplicates and the data are expressed as mean \pm standard error of mean. Significance is set at ${ }^{*} p<0.05$

As Annexin V/FITC analysis relies on the externalization of PS, the adoption of this AO/PI assay was purposely to detect different cellular event or morphological changes of the cells when treated with B1 AMCE sample. Apoptotic features such as membrane blebbing, nucleus condensation, and DNA fragmentation were evidently showed by $\mathrm{AO} / \mathrm{PI}$ staining in the treated $4 \mathrm{~T} 1$ cells, thus strengthen the potential of soursop aqueous extract in inducing apoptosis and inhibiting breast cancer cells [20]. Subsequently, cell cycle analysis was also performed as the deregulation of cell cycle is closely related with apoptosis [21]. The regulation of cell cycle involves several checkpoint pathways to ensure the completion of one phase of the cell cycle before entering into another cycle phase in order to maintain the integrity of cell [22]. A significant increase of cell population at the sub G0/G1 phase was observed and shown in Table 3 which suggested the incident of cell cycle arrest in the B1 AMCE treated group. Halting the cell cycle progression in cancer cells eventually leads to the cell death which befits the idea of treating the breast cancer cells. Our data attested that B1 AMCE is capable of suppressing the tumor growth in the $4 \mathrm{~T} 1$ breast cancer in murine tumor models (after 28 days of treatment) based on the regression of weight and volume of the tumors, in agreement with the in vitro assays (MTT, Annexin V/FITC, AO/PI, cell cycle analysis) results. Additionally, according to the H\&E staining of the tumors, the number of actively dividing cells (i.e., mitosis) which is a distinguished feature of cancer cells was reduced following the treatment of tumor with B1 AMCE when compared to the untreated control tumor. In order to consider that B1 AMCE as a potential candidate for antitumor drug, it is imperative that it possesses the capacity, by any mean, to inhibit the breast cancer cell from metastasize since the progression of tumor is not only dependent upon its proliferative rate. Metastasis which involves the migration and invasion of tumor cells has been long known as a formidable barrier to successful treatment. Therefore, in this present study, B1 AMCE had been put into test in vitro assays to justify this vital feature. In the wound healing 


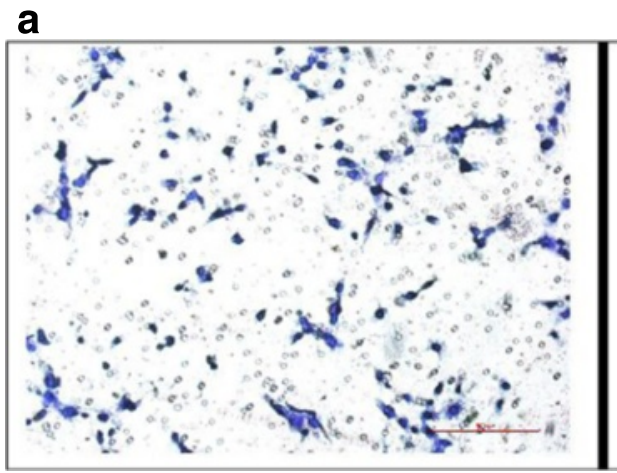

Control

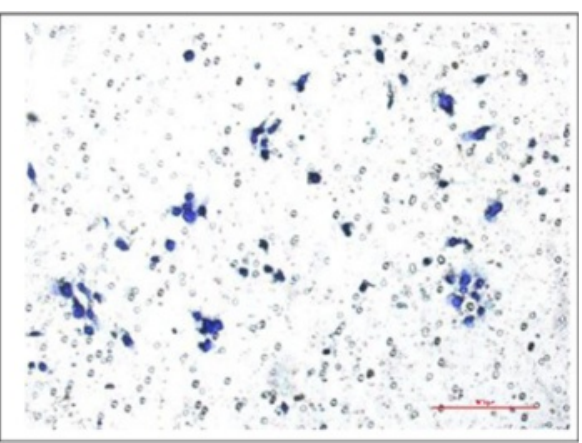

$\mathrm{IC}_{50}$

b

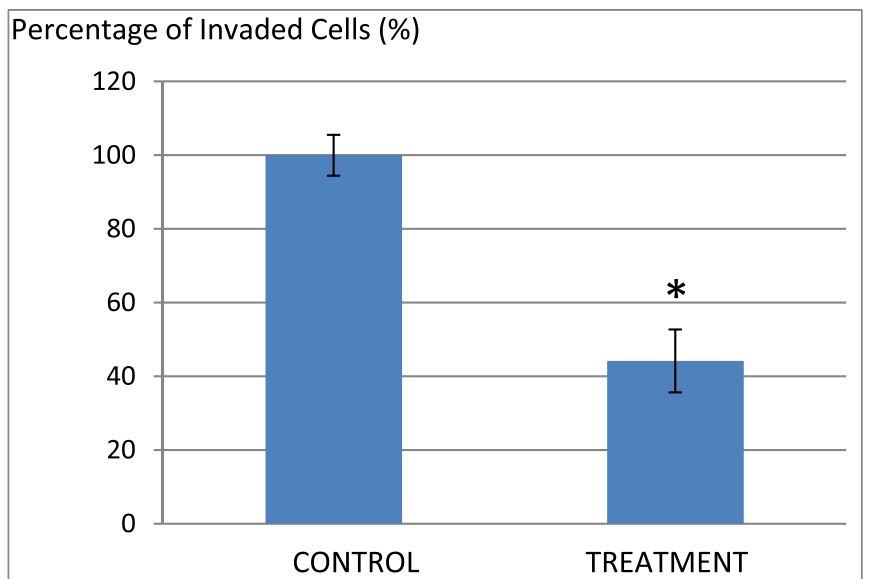

Fig. 9 a Images of the in vitro invasion analysis of $4 \mathrm{~T} 1$ cells; control and cells treated with $\mathrm{IC}_{50}$ value of B1 Annona muricata crude extract. The cells were allowed to invade through a layer of Matrigel for 24 h. $\mathbf{b}$ Quantification of invasion achieved by the B1 AMCE-treated 4 T1 cells as a percentage of that achieved by control cells. The assay was done in triplicates and the data are expressed as mean \pm standard error of mean. Significance is set at ${ }^{*} p<0.05$

assay, B1 AMCE managed to delay the growth of 4 T1 cells towards the centre of the wound which stressed out its propensity to prevent the migration of cancer cells. Hepatocyte growth factor/ scatter factor (HGF/SF), insulin-like growth factor II (IGF-II), and autotaxin which are among several factors reported to contribute to cancer cell motility [23] might be targeted by B1 AMCE but further clarification is required. This anti-metastatic effect was also well observed in the Transwell migration assay and the invasion assay where the number of cancerous cells was decreased in each assay in the presence of the B1 leaf extract. Evidently, this anti-metastatic potential of this plant extract is in accord with the previous finding although the setting of the study was on the pancreatic cancer cells [24]. Along with the in vitro studies, the in vivo studies were also carried out. The distribution of 4 T1 breast cancer cells to the secondary site such as the lung organ of the tumor-bearing mice was decreased in the B1 AMCE treated group as distinguished by the reduction of colonies formed in clonogenic assay. As can be seen in
Fig. 10b, the colony formation was morphologically changed due to the B1 AMCE treatment. The formation of colony from ensembles of cells could be related to cell-cell adhesion and cell motility [25] thus, suggesting that 4 T1 cancer cells became less motile and more adhesive to each other in the presence of B1 AMCE treatment. However, it is noteworthy that there are no published data with specific attention have been reported to issue pertaining to the effect of the sample on colony size. Previous studies has identified that metastasis of tumor is made easier by the formation of new blood vessels at the surrounding matrix allowing a continuous interaction with other cells and systems of the body. As the multiple numbers of factors are involved in angiogenesis including the likes of growth factors, chemokines, cytokines, extracellular matrix macromolecule, and adhesion molecule, the present study was undertaken to observe the expression level of several angiogenesis-related protein in B1 AMCE-treated tumor harvested from tumor-bearing mice on the basis of the angiogenesis proteome profiler. The findings have shown 
a

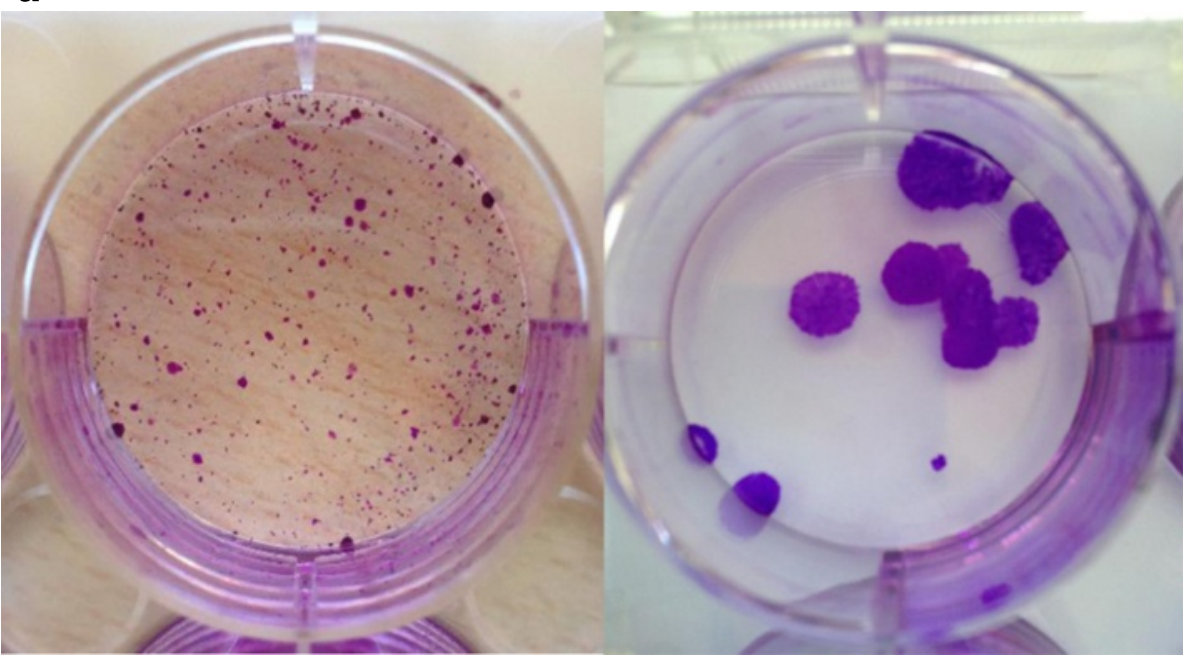

Control

B1 AMCE

b

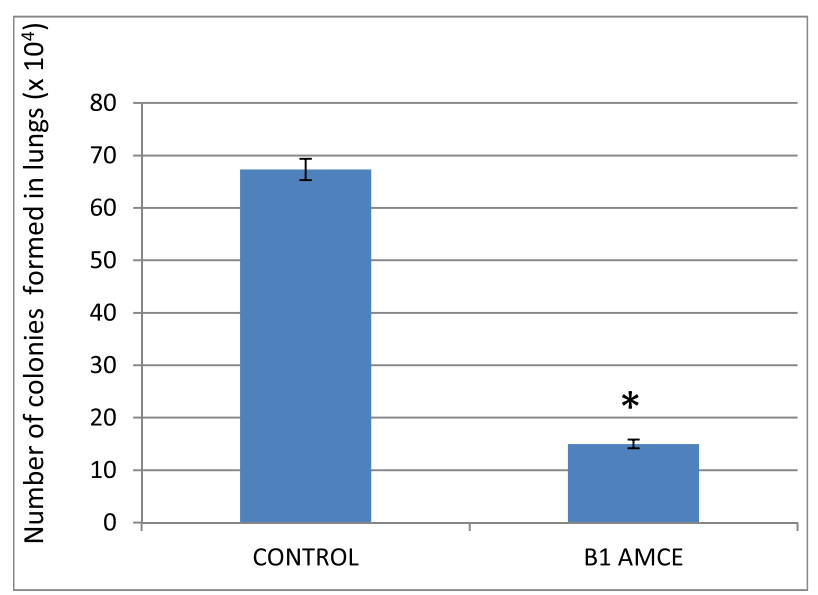

Fig. 10 a Representative images of colonies formed in lung from clonogenic assay. Dilution factor: $10^{-4}$. $\mathbf{b}$ Total $4 \mathrm{~T} 1$ colonies formed from meshed lung harvested from the control and B1 AMCE (1 g/kg)-treated mice after 10 days of incubation. The data are expressed as means \pm standard error of the mean for triplicates. Significance is set at ${ }^{*} p<0.05 ; n=7$ mice per group

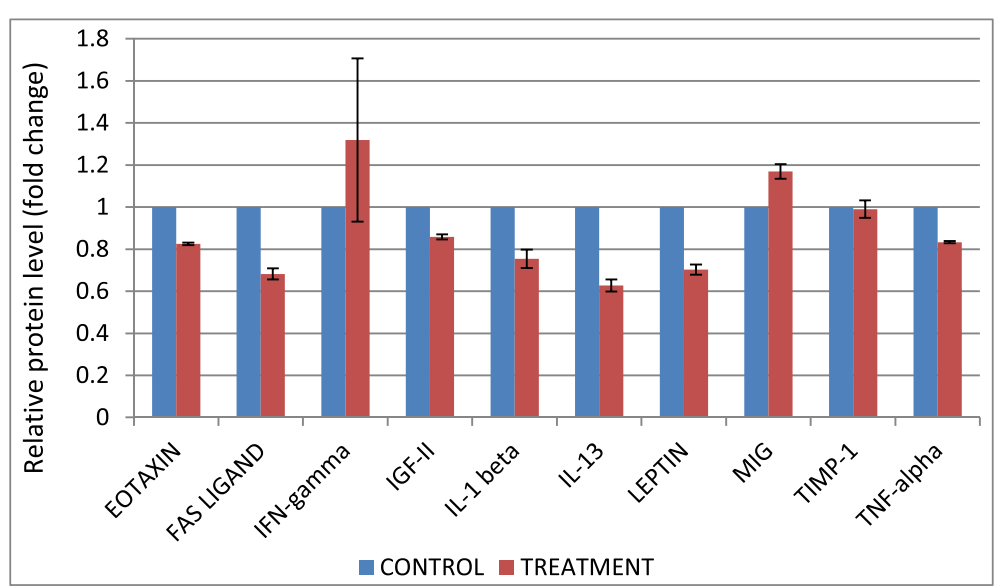

Fig. 11 Significant changes of angiogenesis-related proteins level detected by proteome profiler when treated with B1 AMCE (1 g/kg) 


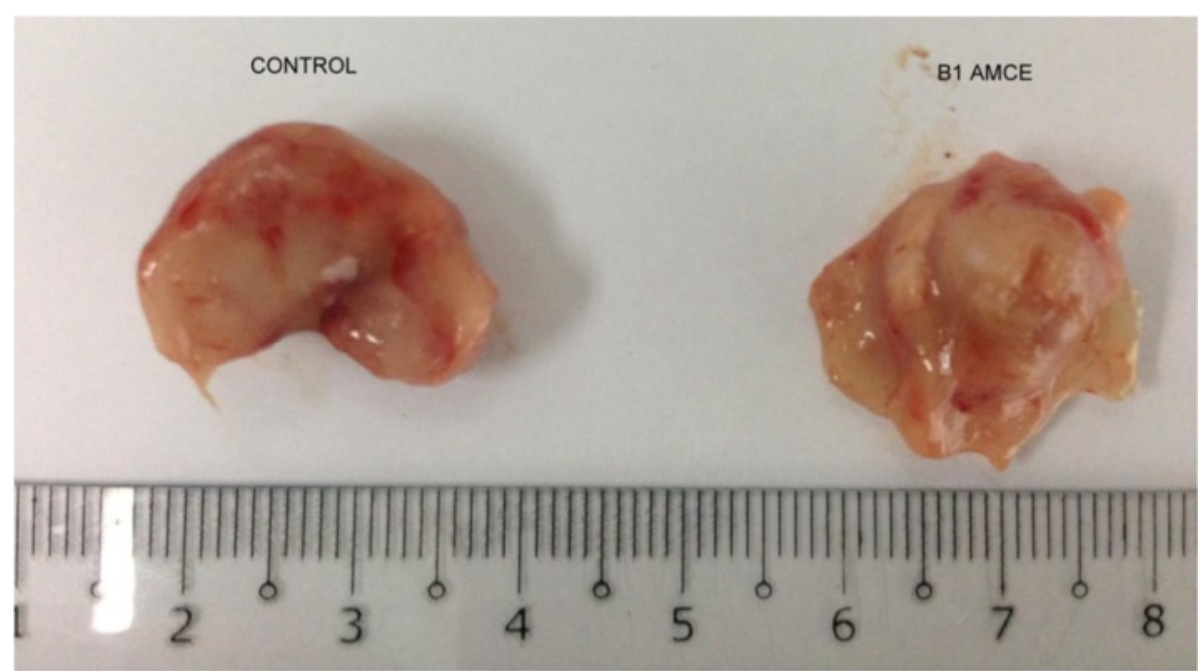

Fig. 12 Images of tumors harvested from control and B1 AMCE (1 g/kg)-treated mice

that protein which includes the likes of Eotaxin, Fas ligand, IGF-II, IL-1 $\beta$, TNF- $\alpha$, IL-13, Leptin, and TIMP-1 were decreased when compared to the untreated tumor. Eotaxin, also referred as CCL11 is a chemokine that could foster angiogenesis through CCR3 receptor. It plays a critical role in inflammatory reactions; allergic and nonallergic as observed in previous studies and was also revealed to be a direct mediator of angiogenesis given the fact that it is an eosinophil chemoattractant which together with the eosinophilic products such as TGF- $\alpha$ and $-\beta$ could induce angiogenesis [26]. Moreover, the level of Fas ligand was reduced significantly in the treated group compared to the untreated group. Fas ligand engagement with its receptor induces the apoptotic cell death and is important in modulating the homeostasis of cells in the

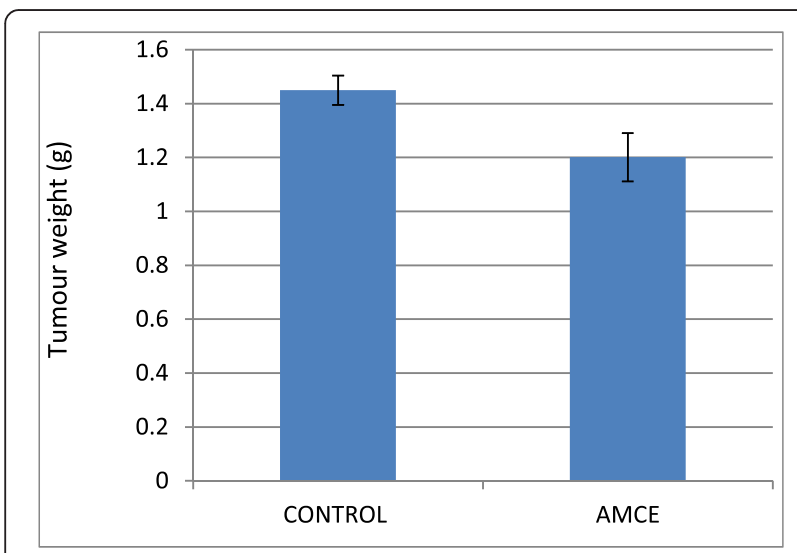

Fig. 13 Weight of the tumors was measured after being harvested from the mice after 28 days of treatment. The data are expressed as means \pm standard error of the mean for triplicates. $n=7$ mice per group immune system where its signal limits the expansion of $\mathrm{T}$ cell clones after the elimination of antigen [27]. In certain location of body such as the eye, testis, and placenta, Fas ligand is found highly expressed resulting in the death of invading $\mathrm{Fas}^{+}$cells, including the lymphocytes which give them a privilege from immune surveillance [28]. Such strategy is also adopted by tumor cells to grant them an escape pass from being targeted by immune system thus, allowing them to successfully grow and proliferate. In addition, the level of insulin-like growth factor-II (IGF-II) is also dropped in the B1 AMCE-treated group. A mature IGF-II together with its homologous polypeptide sequence, IGF-1 and insulin, interact with either the type-1 IGF or insulin receptor located in the plasma membrane to transmit their growth promoting signals [29]. IGF-II level is found elevated in breast cancer patients and its involvement in cancer development could be seen through

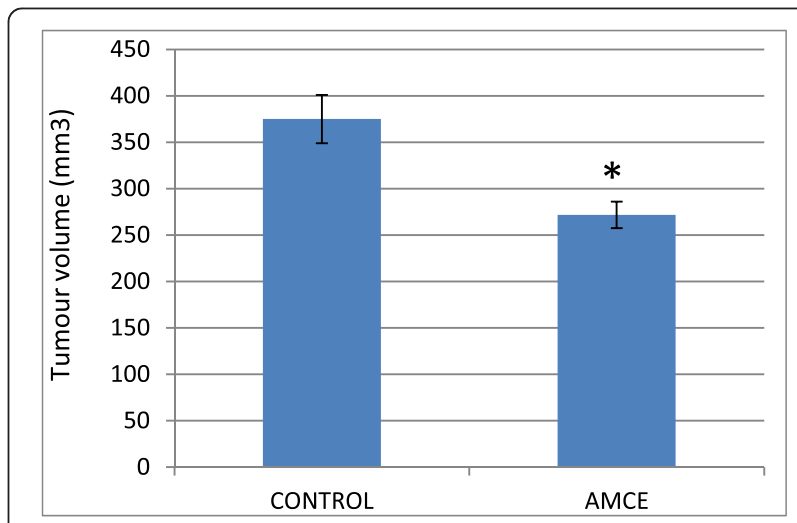

Fig. 14 Volume of the tumors was measured using a vernier caliper. The data are expressed as means \pm standard error of the mean for triplicates. Significance is set at ${ }^{*} p<0.05 ; n=7$ mice per group 


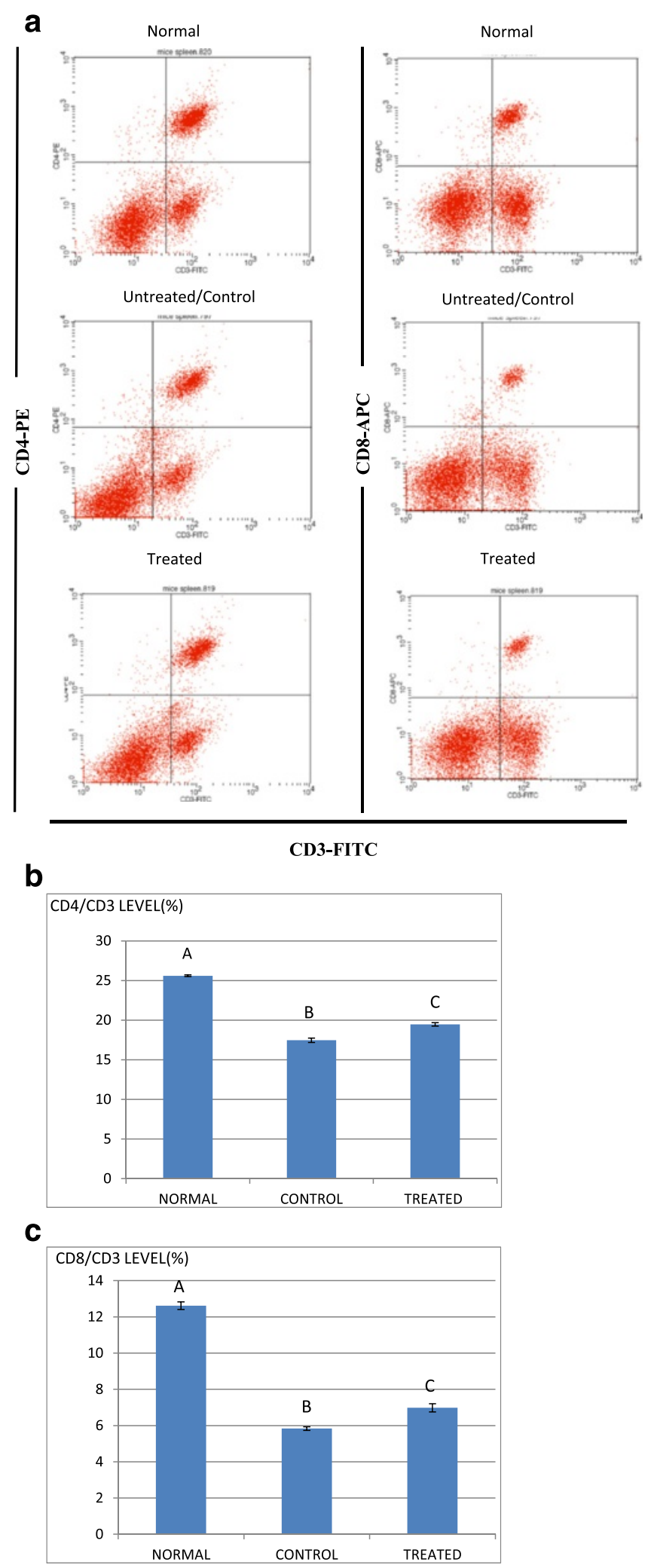

Fig. 15 (See legend on next page.) 
(See figure on previous page.)

Fig. 15 a Flow cytometry analysis of immune markers (CD3, CD4, and CD8) on the splenocytes of the normal, control, and B1 AMCE (1 g/kg)treated mice. $\mathbf{b}$ Percentage of CD4/CD3 T cell population from the spleenocytes of the normal, control and B1 AMCE (1 g/ kg)-treated mice as depicted in Fig. 15a. The data are expressed as means \pm standard error of the mean for triplicates. Mean values with different superscripts are significantly different $p<0.05 ; n=7$ mice per group. $\mathbf{c}$ Percentage of CD8/CD3 T cell population from the spleenocytes of the normal, control and B1 AMCE (1 g/ kg)-treated mice as depicted in Fig. 15a. The data are expressed as means \pm standard error of the mean for triplicates. Mean values with different superscripts are significantly different $p<0.05 ; n=7$ mice per group

the MAPK pathway where IGF signal activates genes concerned with cell proliferation; and reduce the apoptosis event via the PI3-K/Akt pathway, hence, the occurrence of tumorigenesis [30]. Inflammatory cytokines such as tumor necrosis factor- $\alpha$ (TNF- $\alpha$ ) and interleukin-1 $\beta$ (IL-1 $\beta$ ) which are evidently contribute to angiogenesis, are also decreased in the B1 AMCE-treated group. In one study, these inflammatory cytokines alongside with inflammatory chemokines; CCL2 and CCL5 are expressed in a coordinated fashion which provides a combined role of the mediators to supports the growth and progression of breast tumor [31]. Another proangiogenic cytokine, interleukin13 (IL-13) was also significantly less expressed in the treated group. IL-13 which is derived from T-lymphocyte is highly expressed in breast cancer as reported in previous studies and exerts its effect by inducing the upregulation of VCAM-1 which consequently modulates the angiogenesis event [32]. Moreover, the level of tissue inhibitor of metalloproteinase-1 (TIMP-1), a member of the TIMPs family, was slightly decreased in the tumor treated group. The highly expressed TIMP-1 in breast cancer leads to tumor growth and development plus making the cells resistant to multiple apoptotic stimuli through the FAK/PI-3 K/AKT survival signalling pathways [33] despite its other role in inhibiting the MMP from degrading the extracellular matrix as demonstrated in other findings

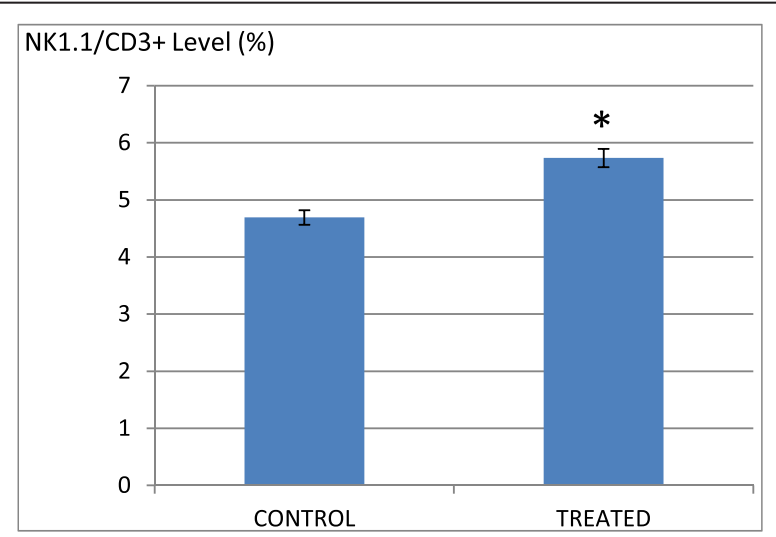

Fig. 16 Percentage of NK1.1/CD3+ T-cell population from spleenocytes assay of the control and B1 AMCE (1 $\mathrm{g} / \mathrm{kg})$-treated mice. The data are expressed as means \pm standard error of the mean for triplicates. Significance is set at ${ }^{*} p<0.05 ; n=7$ mice per group
[34]. On the other hand, leptin which is frequently associated with obesity could also stimulate the proliferation of breast cancer cell lines as outlined in the previous studies $[35,36]$. It is worth noting that its expression level was significantly reduced in the B1 AMCE-treated group. In spite of the decreased expression of several proteins, B1 AMCE could also up-regulates several proteins such as interferon-gamma (IFN- $\gamma$ ) and monokine induced by interferon- $\gamma$ (Mig) which underlines its favourable criteria as anti-cancer agent. It has been discovered that IFN- $\gamma$ has anti-tumoral effect as it manages to inhibit the growth of tumor cell lines including breast cancer cells by causing cell cycle arrest in the expense of p21 up-regulation as reported in previous studies [37] while in another findings, indicate that IFN- $\gamma$ increases the growth inhibitory effect of tamoxifen in breast metastatic carcinomas [38]. The up-regulation of Mig in the treated group is a good indicator for B1 AMCE as anti-angiogenesis agent due to its ability to inhibit angiogenesis in vivo. In the presence of Mig, the neovascularization induced by the angiogenic factors such as IL-8, ENA-78, GCP-2, and GRO $\alpha$ is inhibited [39]. Immune responses are responsible in the eradication of the neoplastic cells via the activation of the CD4 ${ }^{+}$and $\mathrm{CD}^{+} \mathrm{T}$ lymphocytes but a compromise to this barrier system could cost dearly. Based on the previous findings, tumor cells held its own machinery to evade from the immune surveillance by altering the activity of the Tcells thus, ensuring their progression [40]. From our study, it is apparent that the percentage level of the $\mathrm{CD} 4^{+}$and $\mathrm{CD}^{+} \mathrm{T}$ lymphocytes were dropped in the tumor group when compared to the normal group. This situation could be explained by the tumor-releasing Survivin as it has been described in one previous study. It was shown that Survivin, an apoptosis inhibitor, is released into extracellular space before eventually taken up by other surrounding malignant cells which describes their aggressive phenotype in terms of the increase of proliferative rate, resistance towards therapies, and their invasive potential. Survivin is

Table 4 Total white blood cell count in the serum harvested from the control and B1 AMCE (1 g/kg)-treated mice

\begin{tabular}{ll}
\hline MICE & Total white blood cell count, $10^{9} / \mathrm{L}$ \\
\hline Control & 2.4 \\
B1 AMCE & 4.5 \\
\hline
\end{tabular}




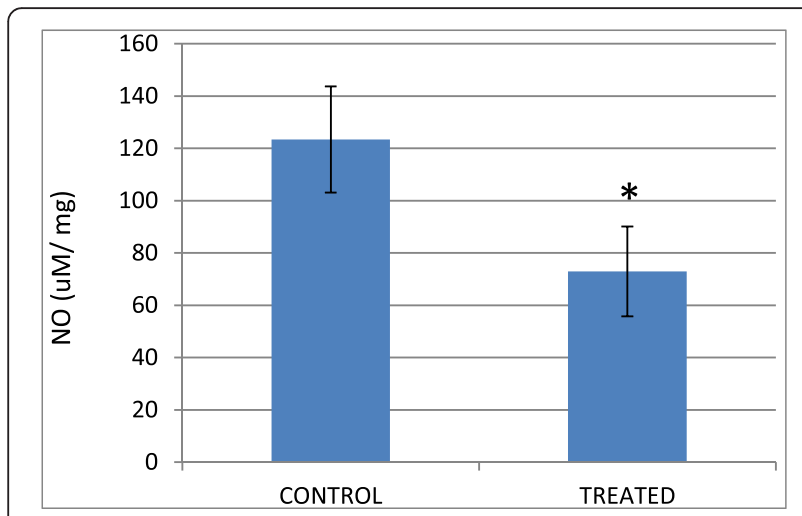

Fig. 17 Level of nitric oxide in the tumors harvested from the control group and B1 AMCE (1 g/kg)-treated group. The data are expressed as means \pm standard error of the mean for triplicates. Significance is set at ${ }^{*} p<0.05 ; n=7$ mice per group

taken up by T-cells as well due to its binding capability which consequently been the causal of the T-cells response polarization where proliferation and cytotoxicity of the T-cells are decreased [41]. Therefore, restoration of the T-cells level back to its normal state is necessary to combat and suppress the cancer cells. In our study, treatment with $\mathrm{B} 1 \mathrm{AMCE}$ in the tumor-bearing mice group marked an increase of $\mathrm{CD}^{+}$and $\mathrm{CD}^{+} \mathrm{T}$ lymphocytes population as well as the NK1.1 level compared to the control untreated group. Both $\mathrm{CD}^{+}{ }^{+}$T-cell and NK cells are responsible in eliminating the cancer by lysing the tumors whereas T-helper cell is vital in further recruiting of both the aforementioned lymphocytes and also the cytokines for anti-tumor response purpose [42]. White blood cells are important in fighting infection and diseases which always appeared low in cancer patients [43] due to cancer itself that spreads beyond bone marrow site and displace the white blood cells or from the chemotherapy

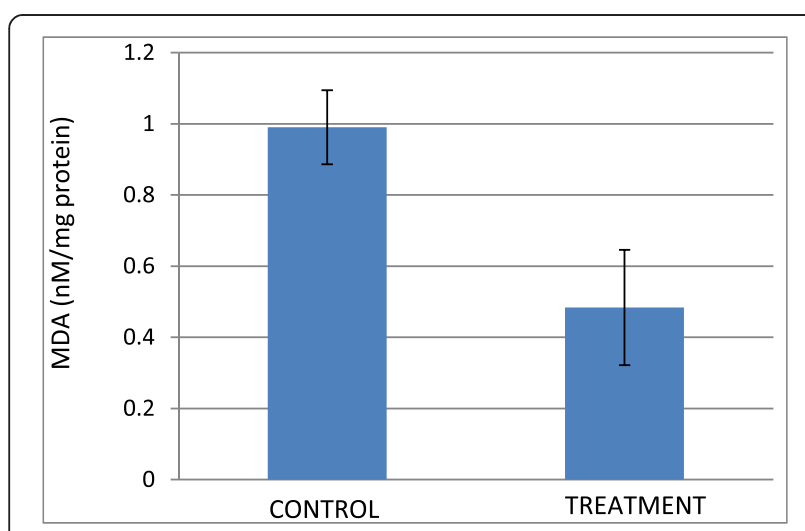

Fig. 18 Level of malondialdehyde (MDA) in the tumors harvested from the control group and B1 AMCE (1 g/ $/ \mathrm{kg})$-treated group. The data are expressed as means \pm standard error of the mean for triplicates. $n=7$ mice per group session. The increase in total white blood cell count may suggest the potential of B1 AMCE as a cancer therapy in recovering the white blood cell loss. Inflammation which is often related to immune modulatory response could initiate the progression of cancer once become chronic. One of the main culprits linking to this association is nitric oxide, a free radical product of NO synthase (NOS) where it is highly expressed in cancer cells and accounts for other multiple reactive intermediates [44]. Persistent expression of this mutagenic NO could contribute to tumor growth, metastasis, and angiogenesis as indicated in previous studies $[45,46]$. Interestingly, B1 AMCE treatment exhibits a good therapeutic profile with a marked decrease of NO level within the tumor. Additionally, lipid peroxidation of polyunsaturated fatty acids is also induced in the wake of inflammatory response where it gives rise to several secondary products including malondialdehye (MDA), a highly toxic molecule $[47,48]$. An intervention of the production of MDA is necessary to inhibit DNA damage and also to treat cancer, in overall perspective [49]. It is apparent that B1 AMCE could decrease the level of MDA within the tumor when compared to the untreated group thereby supporting the therapeutic potential of this leaf crude extract.

\section{Conclusion}

Based on the results obtained from this study, it is imperative to carefully select the soursop samples from its cultivation area as it could determine the potency and anticancer activity of certain soursop sample. B1 AMCE has a good profile to be a candidate for breast cancer treatment as it managed to induce the apoptosis of $4 \mathrm{~T} 1$ breast cancer cells, inhibited the metastasis in vitro and in vivo, regulated the immune system, and reduced the inflammation caused by cancer. Nevertheless, a further evaluation of AMCE is needed to gain knowledge about its anticancer activity and mechanism.

\section{Additional file}

Additional file 1: Table S1. Sampling sites of Annona muricata Linn in Peninsular Malaysia with the code and voucher number of each sample. (DOCX $14 \mathrm{~kb}$ )

\section{Acknowledgement}

We acknowledge the colleagues of the Animal Tissue Culture Laboratory for their assistance throughout this work and are also grateful to Dr Yeap Swee Keong for the helpful discussions in the anti-cancer studies.

\section{Funding}

The authors thank Universiti Putra Malaysia for financing this work through the IPS PUTRA grant No. 9399300. The funders had no role in study design, data collection and analysis or preparation of the manuscript.

\section{Availability of data and materials}

The data will be accessible by contacting the corresponding author of this study. 


\section{Authors' contributions}

All authors conceived and designed the experiment. SUFSN, MFR, and NMANAR performed the experiments and analysed the data. NBA, MH, and NMANAR contributed the reagents/materials/analysis tools. SUFSN and NMANAR contributed to the writing of the manuscript. All authors read and approved the final manuscript.

\section{Competing interests}

The authors declare that they have no competing interests.

\section{Consent for publication}

This study did not involve human participants hence, this information is not relevant. (Not applicable)

\section{Ethics approval and consent to participate}

Ethical approval for the animal study was acquired from Institutional Animal Care and Utilize of Committee of the Faculty Veterinary and Medicine, Universiti Putra Malaysia (Reference Number: UPM/IACUC/AUP/RO55/2015).

\section{Received: 7 February 2016 Accepted: 16 August 2016 Published online: 24 August 2016}

\section{References}

1. Jemal A, et al. Global cancer statistics. CA Cancer J Clin. 2011;61(2):69-90.

2. Bermejo $A$, et al. Acetogenins from Annonaceae: recent progress in isolation, synthesis and mechanisms of action. Nat Prod Rep. 2005;22(2):269-303

3. Kim GS, et al. Muricoreacin and murihexocin C, mono-tetrahydrofuran acetogenins, from the leaves of Annona muricata. Phytochemistry. 1998:49(2):565-71.

4. Rieser MJ, et al. Five novel mono-tetrahydrofuran ring acetogenins from the seeds of Annona muricata. J Nat Prod. 1996;59(2):100-8.

5. Alali FQ, Liu XX, McLaughlin JL. Annonaceous acetogenins: recent progress. J Nat Prod. 1999;62(3):504-40.

6. McLaughlin JL. Paw paw and cancer: annonaceous acetogenins from discovery to commercial products. J Nat Prod. 2008;71(7):1311-21.

7. Degli Esposti $M$, et al. Natural substances (acetogenins) from the family Annonaceae are powerful inhibitors of mitochondrial NADH dehydrogenase (Complex I). Biochem J. 1994;301(1):161-7.

8. Guo L, et al. Effects of ecological factors on secondary metabolites and inorganic elements of Scutellaria baicalensis and analysis of geoherblism. Sci China Life Sci. 2013;56(11):1047-56.

9. Zhi-Dong $L$, et al. Curcumin induces apoptosis in breast cancer cells and inhibits tumor growth in vitro and in vivo. Int J Clin Exp Pathol. 2014;7(6):2818-24

10. Salim LZA, et al. Thymoquinone induces mitochondria-mediated apoptosis in acute lymphoblastic leukaemia in vitro. Molecules. 2013;18:11219-40.

11. Chen HC. Boyden chamber assay. Methods Mol Biol. 2005:294:15-22.

12. Liang CC, Park AY, Guan JL. In vitro scratch assay: a convenient and inexpensive method for analysis of cell migration in vitro. Nat Protoc. 2007;2(2):329-33.

13. DuPre SA, Redelman D, Hunter Jr KW. The mouse mammary carcinoma 4T1: characterization of the cellular landscape of primary tumours and metastatic tumour foci. Int J Exp Pathol. 2007;88(5):351-60.

14. George VC, et al. Quantitative assessment of the relative antineoplastic potential of the n-butanolic leaf extract of Annona muricata Linn. in normal and immortalized human cell lines. Asian Pac J Cancer Prev. 2012;13(2):699-704.

15. Gull J, et al. Variation in antioxidant attributes at three ripening stages of guava (Psidium guajava L.) fruit from different geographical regions of Pakistan. Molecules. 2012;17(3):3165-80.

16. Selmar D, Kleinwachter M. Stress enhances the synthesis of secondary plant products: the impact of stress-related over-reduction on the accumulation of natural products. Plant Cell Physiol. 2013;54(6):817-26.

17. Lee JE, et al. Geographical and climatic dependencies of green tea (Camellia sinensis) metabolites: a (1)H NMR-based metabolomics study. J Agric Food Chem. 2010;58(19):10582-9.

18. Al-Gabbiesh A, Kleinwachter M, Selmar D. Influencing the contents of secondary metabolites in spice and medicinal plants by deliberately applying drought stress during their cultivation. Jordan J Biol Sci. 2015;8(1):1-10.
19. Zorofchian Moghadamtousi S, et al. Annona muricata leaves induce G(1) cell cycle arrest and apoptosis through mitochondria-mediated pathway in human HCT-116 and HT-29 colon cancer cells. J Ethnopharmacol. 2014;156:277-89.

20. Aziz MY, et al. Damnacanthal is a potent inducer of apoptosis with anticancer activity by stimulating p53 and p21 genes in MCF-7 breast cancer cells. Oncol Lett. 2014;7(5):1479-84.

21. Dai $Y$, et al. Selective growth inhibition of human breast cancer cells by graviola fruit extract in vitro and in vivo involving downregulation of EGFR expression. Nutr Cancer. 2011;63(5):795-801.

22. Dickson MA, Schwartz GK. Development of cell-cycle inhibitors for cancer therapy. Curr Oncol. 2009;16(2):36-43.

23. Yang $D$, et al. Effects of osthole on migration and invasion in breast cancer cells. Biosci Biotechnol Biochem. 2010;74(7):1430-4.

24. Torres MP, et al. Graviola: a novel promising natural-derived drug that inhibits tumorigenicity and metastasis of pancreatic cancer cells in vitro and in vivo through altering cell metabolism. Cancer Lett. 2012:323(1):29-40

25. Sungkaworn $\mathrm{T}$, et al. The effects of $\mathrm{TiO}_{2}$ nanoparticles on tumor cell colonies: fractal dimension and morphological properties. Int J Medical Health Biomed Bioeng Pharm Eng. 2008;2(1):20-7.

26. Salcedo $\mathrm{R}$, et al. Eotaxin (CCL11) induces in vivo angiogenic responses by human CCR3+ endothelial cells. J Immunol. 2001;166(12):7571-8.

27. Peter ME, et al. The role of CD95 and CD95 ligand in cancer. Cell Death Differ. 2015;22(5):885-6.

28. Mor $\mathrm{G}$, et al. Regulation of fas ligand expression in breast cancer cells by estrogen: functional differences between estradiol and tamoxifen. J Steroid Biochem Mol Biol. 2000;73(5):185-94.

29. Qiu J, et al. Risk factors for breast cancer and expression of insulin-like growth factor-2 (IGF-2) in women with breast cancer in Wuhan City, China. PLoS One. 2012:7(5):36497.

30. Livingstone C. IGF2 and cancer. Endocr Relat Cancer. 2013;20(6):321-39.

31. Soria $G$, et al. Inflammatory mediators in breast cancer: coordinated expression of TNFalpha \& IL-1 beta with CCL2 \& CCL5 and effects on epithelial-to-mesenchymal transition. BMC Cancer. 2011;11:130.

32. Fukushi J, et al. The activity of soluble VCAM-1 in angiogenesis stimulated by IL-4 and IL-13. J Immunol. 2000;165(5):2818-23.

33. Zhu D, et al. High expression of TIMP-1 in human breast cancer tissues is a predictive of resistance to paclitaxel-based chemotherapy. Med Oncol. 2012;29(5):3207-15.

34. Wurtz SO, et al. Tissue inhibitor of metalloproteinases-1 in breast cancer. Endocr Relat Cancer. 2005;12(2):215-27.

35. Artac M, Altundag K. Leptin and breast cancer: an overview. Med Oncol. 2012:29(3):1510-4

36. Alshaker $\mathrm{H}$, et al. Leptin induces upregulation of sphingosine kinase 1 in oestrogen receptor-negative breast cancer via Src family kinase-mediated, janus kinase 2-independent pathway. Breast Cancer Res. 2014;16(5):426.

37. Garcia-Tunon I, et al. Influence of IFN-gamma and its receptors in human breast cancer. BMC Cancer. 2007;7:158.

38. Ning $Y$, et al. IFNgamma restores breast cancer sensitivity to fulvestrant by regulating STAT1, IFN regulatory factor 1, NF-kappaB, BCL2 family members, and signaling to caspase-dependent apoptosis. Mol Cancer Ther. 2010;9(5):1274-85.

39. Sgadari $C$, et al. Mig, the monokine induced by interferon-gamma, promotes tumor necrosis in vivo. Blood. 1997;89(8):2635-43.

40. Jiang $Y$, Li Y, Zhu B. T-cell exhaustion in the tumor microenvironment Cell Death Dis. 2015;6:1792.

41. Jutzy JM, et al. Tumor-released survivin induces a type-2 t cell response and decreases cytotoxic T cell function, in vitro. Cancer Microenviron. 2013;6(1):57-68

42. Igney FH, Krammer PH. Immune escape of tumors: apoptosis resistance and tumor counterattack. J Leukoc Biol. 2002;71(6):907-20.

43. Cihan YB, Arslan A, Ergul MA. Subtypes of white blood cells in patients with prostate cancer or benign prostatic hyperplasia and healthy individuals. Asian Pac J Cancer Prev. 2013:14(8):4779-83.

44. Lala PK, Chakraborty C. Role of nitric oxide in carcinogenesis and tumour progression. Lancet Oncol. 2001;2(3):149-56.

45. Choudhari SK, et al. Nitric oxide and cancer: a review. World J Surg Oncol. 2013;11:118

46. Papapetropoulos A, et al. Nitric oxide production contributes to the angiogenic properties of vascular endothelial growth factor in human endothelial cells. J Clin Invest. 1997;100(12):3131-9. 
47. Barrera G. Oxidative stress and lipid peroxidation products in cancer progression and therapy. ISRN Oncol. 2012;2012:137289.

48. Del Rio D, Stewart AJ, Pellegrini N. A review of recent studies on malondialdehyde as toxic molecule and biological marker of oxidative stress. Nutr Metab Cardiovasc Dis. 2005;15(4):316-28.

49. Gago-Dominguez $\mathrm{M}$, et al. Role of lipid peroxidation in the epidemiology and prevention of breast cancer. Cancer Epidemiol Biomarkers Prev. 2005;14(12):2829-39.

Submit your next manuscript to BioMed Central and we will help you at every step:

- We accept pre-submission inquiries

- Our selector tool helps you to find the most relevant journal

- We provide round the clock customer support

- Convenient online submission

- Thorough peer review

- Inclusion in PubMed and all major indexing services

- Maximum visibility for your research

Submit your manuscript at www.biomedcentral.com/submit 